\title{
Biogeochemical processes and buffering capacity concurrently affect acidification in a seasonally hypoxic coastal marine basin
}

\author{
M. Hagens ${ }^{1}$, C. P. Slomp ${ }^{1}$, F. J. R. Meysman ${ }^{2,3}$, D. Seitaj ${ }^{2}$, J. Harlay ${ }^{4, *}$, A. V. Borges ${ }^{4}$, and J. J. Middelburg ${ }^{1}$ \\ ${ }^{1}$ Department of Earth Sciences, Faculty of Geosciences, Utrecht University, Utrecht, the Netherlands \\ ${ }^{2}$ Department of Ecosystem Studies, Royal Netherlands Institute for Sea Research, Yerseke, the Netherlands \\ ${ }^{3}$ Department of Analytical, Environmental and Geochemistry, Faculty of Science, Vrije Universiteit Brussel, \\ Brussels, Belgium \\ ${ }^{4}$ Chemical Oceanography Unit, University of Liège, Liège, Belgium \\ * present address: Department of Oceanography, University of Hawaii, Honolulu, Hawaii, USA
}

Correspondence to: M. Hagens (m.hagens@uu.nl)

Received: 13 October 2014 - Published in Biogeosciences Discuss.: 19 November 2014

Revised: 5 February 2015 - Accepted: 18 February 2015 - Published: 11 March 2015

\begin{abstract}
Coastal areas are impacted by multiple natural and anthropogenic processes and experience stronger $\mathrm{pH}$ fluctuations than the open ocean. These variations can weaken or intensify the ocean acidification signal induced by increasing atmospheric $p \mathrm{CO}_{2}$. The development of eutrophicationinduced hypoxia intensifies coastal acidification, since the $\mathrm{CO}_{2}$ produced during respiration decreases the buffering capacity in any hypoxic bottom water. To assess the combined ecosystem impacts of acidification and hypoxia, we quantified the seasonal variation in $\mathrm{pH}$ and oxygen dynamics in the water column of a seasonally stratified coastal basin (Lake Grevelingen, the Netherlands).

Monthly water-column chemistry measurements were complemented with estimates of primary production and respiration using $\mathrm{O}_{2}$ light-dark incubations, in addition to sediment-water fluxes of dissolved inorganic carbon (DIC) and total alkalinity (TA). The resulting data set was used to set up a proton budget on a seasonal scale.

Temperature-induced seasonal stratification combined with a high community respiration was responsible for the depletion of oxygen in the bottom water in summer. The surface water showed strong seasonal variation in process rates (primary production, $\mathrm{CO}_{2}$ air-sea exchange), but relatively small seasonal $\mathrm{pH}$ fluctuations ( 0.46 units on the total hydrogen ion scale). In contrast, the bottom water showed less seasonality in biogeochemical rates (respiration, sedimentwater exchange), but stronger $\mathrm{pH}$ fluctuations (0.60 units). This marked difference in $\mathrm{pH}$ dynamics could be attributed
\end{abstract}

to a substantial reduction in the acid-base buffering capacity of the hypoxic bottom water in the summer period. Our results highlight the importance of acid-base buffering in the $\mathrm{pH}$ dynamics of coastal systems and illustrate the increasing vulnerability of hypoxic, $\mathrm{CO}_{2}$-rich waters to any acidifying process.

\section{Introduction}

The absorption of anthropogenic carbon dioxide $\left(\mathrm{CO}_{2}\right)$ has decreased the average $\mathrm{pH}$ of open ocean surface water by ca. 0.1 unit since the Industrial Revolution (Orr et al., 2005). In coastal areas, the problem of ocean acidification is more complex, as seawater $\mathrm{pH}$ is influenced by various natural and anthropogenic processes other than $\mathrm{CO}_{2}$ uptake (Borges and Gypens, 2010; Duarte et al., 2013; Hagens et al., 2014). As a result, the signal of $\mathrm{CO}_{2}$-induced acidification may not be readily discernible in coastal systems, as time series of $\mathrm{pH}$ show high variations at diurnal, seasonal and decadal timescales (e.g. Hofmann et al., 2011; Wootton and Pfister, 2012). One major anthropogenic process impacting coastal $\mathrm{pH}$ is eutrophication (Borges and Gypens, 2010; Provoost et al., 2010; Cai et al., 2011). Enhanced inputs of nutrients lead to higher rates of both primary production and respiration (Nixon, 1995), thereby increasing the variability in $\mathrm{pH}$ on both the diurnal (Schulz and Riebesell, 2013) and seasonal scales (Omstedt et al., 2009). Moreover, when pri- 
mary production and respiration are not balanced, they can lead to longer-term changes in $\mathrm{pH}$ at rates that can strongly exceed the expected $\mathrm{pH}$ decrease based on rising atmospheric $\mathrm{CO}_{2}$ (Borges and Gypens, 2010). The direction of this eutrophication-induced $\mathrm{pH}$ change depends on the sign of the imbalance, and the resulting $\mathrm{pH}$ trend can be sustained for decades (Provoost et al., 2010; Duarte et al., 2013).

A well-known effect of eutrophication is the development of hypoxia in coastal bottom waters (Diaz and Rosenberg, 2008). Such bottom-water oxygen $\left(\mathrm{O}_{2}\right)$ depletion occurs when the $\mathrm{O}_{2}$ consumption during respiration exceeds the supply of oxygen-rich waters and typically develops seasonally as a result of summer stratification and enhanced biological activity. As respiration of organic matter produces $\mathrm{CO}_{2}$ at a rate proportional to $\mathrm{O}_{2}$ consumption (Redfield et al., 1963), it follows that zones of low $\mathrm{O}_{2}$ are also zones of high $\mathrm{CO}_{2}$ (hypercapnia) and thus show high levels of dissolved inorganic carbon (DIC) and low pH (Brewer and Peltzer, 2009; Howarth et al., 2011). In coastal bays, oxygen and carbonate system parameters co-vary on both diurnal (Burnett, 1997) and seasonal timescales (Frankignoulle and Distèche, 1984; Melzner et al., 2013), where the diurnal variability may be of similar magnitude to the seasonal variability (Yates et al., 2007). Primary production and respiration are often spatially and temporally decoupled, as phytoplankton biomass is produced during spring blooms in the surface water, subsequently sinks, and is degraded with a time lag in the bottom water and sediment. In seasonally stratified areas, this can lead to significant concomitant drops in bottom-water $\mathrm{pH}$ and $\mathrm{O}_{2}$ in summer, as has been shown for the Seto Inland Sea (Taguchi and Fujiwara, 2010), the northern Gulf of Mexico and the East China Sea (Cai et al., 2011), the Bohai Sea (Zhai et al., 2012), the Gulf of Trieste (Cantoni et al., 2012), several estuarine bays across the northeastern US coast (Wallace et al., 2014), the semi-enclosed Lough Hyne (Sullivan et al., 2014) and in areas just off the Changjiang Estuary (Wang et al., 2013).

Long-term trends in $\mathrm{pH}$ resulting from increased prevalence of bottom-water hypoxia can be substantial compared to the $\mathrm{pH}$ trend resulting from anthropogenic $\mathrm{CO}_{2}$-induced acidification. Data from the Lower St Lawrence Estuary indicate that the decrease in bottom-water $\mathrm{pH}$ over the past 75 years is $4-6$ times higher than can be explained by the uptake of anthropogenic $\mathrm{CO}_{2}$ alone (Mucci et al., 2011). In Puget Sound, respiration currently accounts for $51-76 \%$ of the decrease in subsurface water $\mathrm{pH}$ since pre-industrial times, although this fraction will likely decrease as atmospheric $\mathrm{CO}_{2}$ continues to increase (Feely et al., 2010). Model simulations for the northern Gulf of Mexico show that the seasonal drop in bottom-water $\mathrm{pH}$ has increased in the Anthropocene because of a decline in its buffering capacity (Cai et al., 2011), an effect that is most pronounced in eutrophied waters (Sunda and Cai, 2012).

The acid-base buffering capacity $(\beta)$, also termed the buffer intensity or buffer factor, is the ability of an aqueous solution to buffer changes in $\mathrm{pH}$ or proton $\left(\mathrm{H}^{+}\right)$concentration upon the addition of a strong acid or base (Morel and Hering, 1993; Stumm and Morgan, 1996). It is of great importance when considering the effect of biogeochemical processes on pH (Zhang, 2000; Soetaert et al., 2007; Hofmann et al., 2010a). A system with a high acid-base buffering capacity is efficient in attenuating changes in $\left[\mathrm{H}^{+}\right]$and thus displays a smaller net $\mathrm{pH}$ change compared to systems with a low $\beta$. Thus, if two aqueous systems are exposed to the same biogeochemical processes at exactly the same rate, the system with the lower $\beta$ will show $\mathrm{pH}$ excursions with larger amplitudes.

In the 21st century, seawater buffering capacity is expected to decline as a result of increasing $\mathrm{CO}_{2}$ and the subsequent decrease in pH (Egleston et al., 2010; Hofmann et al., 2010a; Hagens et al., 2014). As a result, one would predict a greater seasonal pH variability (Frankignoulle, 1994; Egleston et al., 2010) and a more pronounced diurnal $\mathrm{pH}$ variability in highly productive coastal environments (Schulz and Riebesell, 2013; Shaw et al., 2013), which may additionally be modified by ecosystem feedbacks (Jury et al., 2013). In seasonal hypoxic systems, model analysis predicts more pronounced fluctuations in bottom-water $\mathrm{pH}$ (Sunda and Cai, 2012). However, detailed studies of the effects of seasonal hypoxia on $\mathrm{pH}$ buffering and dynamics are currently lacking.

Here we present a detailed study of the $\mathrm{pH}$ dynamics and acid-base buffering capacity in a temperate coastal basin with seasonal hypoxia (Lake Grevelingen). We quantify the impact of individual processes, i.e. primary production, community respiration, sediment effluxes and $\mathrm{CO}_{2}$ air-sea exchange, on $\mathrm{pH}$ using the method developed by Hofmann et al. (2010a), which uses DIC and $\left[\mathrm{H}^{+}\right]$, rather than total alkalinity (TA), to quantify the carbonate system. From this, we construct a proton budget that attributes proton production or consumption to these processes. Our aim is to quantify seasonal changes in the acid-base buffering capacity and elucidate their importance for carbon cycling and $\mathrm{pH}$ dynamics in coastal hypoxic systems.

\section{Methods}

\subsection{Site description}

Lake Grevelingen, located in the southwestern delta area of the Netherlands, is a coastal marine lake with a surface area of $115 \mathrm{~km}^{2}$ and an average water depth of $5.1 \mathrm{~m}$ (Nienhuis, 1978; Fig. 1). The bathymetry of the lake is characterised by deep gullies intersecting extended shallow areas; half of the lake is shallower than $2.6 \mathrm{~m}$, and only $12.4 \%$ of the lake is deeper than $12.5 \mathrm{~m}$. In the main gully, several deep basins are present, which are separated from each other by sills. The deepest basin extends down to $45 \mathrm{~m}$ water depth. Originally, Lake Grevelingen was an estuary with a tidal range of about $2.3 \mathrm{~m}$. A large flooding event in 1953 was the mo- 


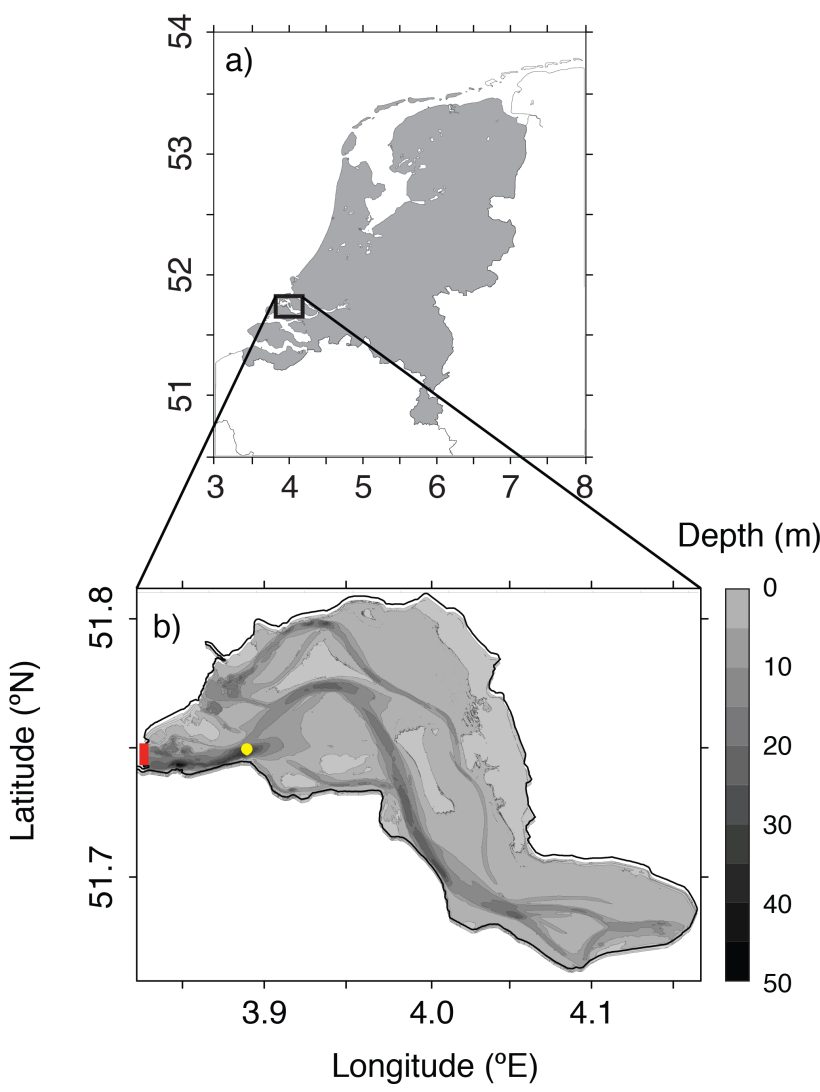

Figure 1. (a) Map of the Netherlands; (b) bathymetry of Lake Grevelingen (data from the executive arm of the Dutch Ministry of Infrastructure and the Environment). Yellow dot indicates sampling location at the deepest point of the Den Osse basin $\left(\mathrm{S} 1 ; 51.747^{\circ} \mathrm{N}\right.$, $\left.3.890^{\circ} \mathrm{E}\right)$. Red bar indicates sluice location.

tive for the construction of two dams. The Grevelingen estuary was closed off on the landward side in 1964 and on the seaward side in 1971. This isolation led to a freshening of the system, with vast changes in water chemistry and biology (Bannink et al., 1984). To counteract these water quality problems, a sluice extending vertically between 3 and $11 \mathrm{~m}$ depth was constructed on the seaward side in 1978 (Pieters et al., 1985). Exchange with saline North Sea water has dominated the water budget since, resulting in the lake approaching coastal salinity (29-32) and an estimated basin-wide water residence time of 229 days (Meijers and Groot, 2007). Upon intrusion, the denser North Sea water forms a distinct subsurface layer, which is then laterally transported into the lake. Yet it has been found that opening the sluice hardly affects water-column mixing (Nolte et al., 2008), and the water quality problems persist. Monthly monitoring carried out by the executive arm of the Dutch Ministry of Infrastructure and the Environment revealed that the main gully of Lake Grevelingen has experienced seasonal stratification and hypoxia since the start of the measurements in 1978, which have differed in extent and intensity annually (Wetsteyn, 2011).

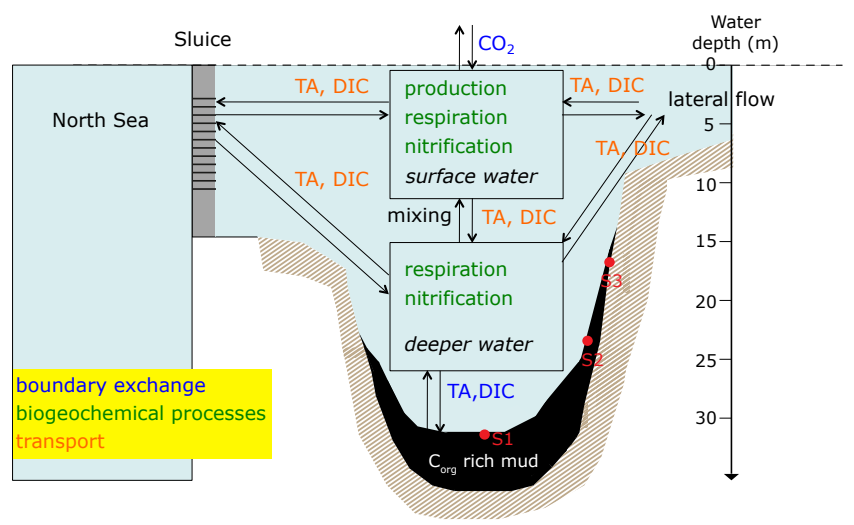

Figure 2. Schematic overview of the main processes affecting the Den Osse proton budget. $\mathrm{C}_{\text {org }}$ refers to organic carbon; see Sect. 2.8 for a detailed explanation of the budget.

Throughout 2012, we performed monthly sampling campaigns on board the R/V Luctor, examining water-column chemistry, biogeochemical process rates and sediment-water exchange. Sampling occurred in the Den Osse basin (maximum water depth $34 \mathrm{~m}$; Fig. 2), a basin located in the main gully of Lake Grevelingen. Two sills surround the basin at water depths of 10 and $20 \mathrm{~m}$ at the landward and seaward sides, respectively. Due to its bathymetry, particulate matter rapidly accumulates within the deeper parts of the basin (sediment accumulation rate $>2 \mathrm{~cm} \mathrm{yr}^{-1}$; Malkin et al., 2014). The surface area and total volume of the Den Osse basin have been estimated at $649 \times 10^{4} \mathrm{~m}^{2}$ and $655 \times 10^{5} \mathrm{~m}^{3}$, respectively (Pieters et al., 1985), resulting in an average water depth of ca. $10 \mathrm{~m}$. Sampling occurred at three stations along a depth gradient within the basin (Fig. 1b): S1 at $34 \mathrm{~m}$ water depth and located at the deepest point of the basin $\left(51.747^{\circ} \mathrm{N}, 3.890^{\circ} \mathrm{E}\right), \mathrm{S} 2$ at $23 \mathrm{~m}\left(51.749^{\circ} \mathrm{N}, 3.897^{\circ} \mathrm{E}\right)$ and $\mathrm{S} 3$ at $17 \mathrm{~m}\left(51.747^{\circ} \mathrm{N}, 3.898^{\circ} \mathrm{E}\right)$. Each campaign, watercolumn sampling was performed at station S1. Discrete water-column samples were collected with a $12 \mathrm{~L}$ Niskin bottle at eight different depths $(1,3,6,10,15,20,25$ and $32 \mathrm{~m})$ to assess the carbonate system parameters ( $\mathrm{pH}$, partial pressure of $\mathrm{CO}_{2}\left(p \mathrm{CO}_{2}\right)$, total alkalinity (TA) and DIC), concentrations of $\mathrm{O}_{2}$, hydrogen sulphide $\left(\mathrm{H}_{2} \mathrm{~S}\right)$, dissolved organic carbon (DOC) and nutrients, and rates of community metabolism. All water samples were collected from the Niskin bottle with gas-tight Tygon tubing. A YSI6600 CTD probe was used to record depth profiles of temperature $(T)$, salinity $(S)$, pressure $(p)$ and chlorophyll $a(\mathrm{Chl} a)$. To determine sediment-water exchange fluxes, intact, undisturbed sediment cores $(6 \mathrm{~cm} \varnothing)$ were retrieved with a UWITEC gravity corer in March, May, August and November 2012 at the three stations S1, S2 and S3. Sampling usually took place mid-morning to minimise the influence of diurnal variability in determining the seasonal trend. The exact dates and times of sampling are provided in the online supplementary information. 


\subsection{Stratification-related parameters}

From $T, S$ and $p$ the water density $\rho_{\mathrm{w}}\left(\mathrm{kg} \mathrm{m}^{-3}\right)$ was calculated according to Feistel (2008) using the package AquaEnv (Hofmann et al., 2010b) in the open-source programming framework $R$. Subsequently, the density anomaly $\sigma_{\mathrm{T}}\left(\mathrm{kg} \mathrm{m}^{-3}\right)$ was defined by subtracting $1000 \mathrm{~kg} \mathrm{~m}^{-3}$ from the calculated value of $\rho_{\mathrm{w}}$. Water density profiles were also used to calculate the stratification parameter $\phi\left(\mathrm{J} \mathrm{m}^{-3}\right)$, which represents the amount of energy required to fully homogenise the water column through vertical mixing (Simpson, 1981):

$\phi=\frac{1}{h} \int_{-h}^{0}\left(\rho_{\mathrm{av}}-\rho_{\mathrm{w}}\right) g z \mathrm{~d} z$ with $\rho_{\mathrm{av}}=\frac{1}{h} \int_{-h}^{0} \rho_{\mathrm{w}} z \mathrm{~d} z$,

where $h$ is the total height of the water column (m), $z$ is depth (m), $g$ is gravitational acceleration $\left(\mathrm{m} \mathrm{s}^{-2}\right)$, and $\rho_{\mathrm{av}}$ is the average water-column density $\left(\mathrm{kg} \mathrm{m}^{-3}\right)$.

Samples for the determination of $\left[\mathrm{O}_{2}\right]$ were drawn from the Niskin bottle into volume-calibrated clear borosilicate biochemical oxygen demand (BOD) bottles of ca. $120 \mathrm{~mL}$ (Schott). $\mathrm{O}_{2}$ concentrations were measured using an automated Winkler titration procedure with potentiometric endpoint detection (Mettler Toledo DL50 titrator and a platinum redox electrode). Reagents and standardisations were as described by Knap et al. (1994).

During summer months we examined the presence of $\mathrm{H}_{2} \mathrm{~S}$ in the bottom water. Water samples were collected in $60 \mathrm{~mL}$ glass serum bottles, which were allowed to overflow and promptly closed with a gas-tight rubber stopper and screw cap. To trap the $\mathrm{H}_{2} \mathrm{~S}$ as zinc sulphide, $1.2 \mathrm{~mL}$ of $2 \%$ zinc acetate solution was injected through the rubber stopper into the sample using a glass syringe and needle. A second needle was inserted simultaneously through the rubber stopper to release the overpressure. The sample was stored upside down at $4{ }^{\circ} \mathrm{C}$ until analysis. Spectrophotometric estimation of $\mathrm{H}_{2} \mathrm{~S}$ (Strickland and Parsons, 1972) was conducted by adding $1.5 \mathrm{~mL}$ of sample and $0.120 \mathrm{~mL}$ of an acidified solution of phenylenediamine and ferric chloride to a disposable cuvette. The cuvette was closed immediately thereafter to prevent the escape of $\mathrm{H}_{2} \mathrm{~S}$ and was allowed to react for a minimum of $30 \mathrm{~min}$ before the absorbance at $670 \mathrm{~nm}$ was measured. For calibration, a $2 \mathrm{mmol} \mathrm{L}^{-1}$ sulphide solution was prepared, for which the exact concentration was determined by iodometric titration.

\subsection{Carbonate system parameters}

For the determination of TA, two separate samples were collected in $50 \mathrm{~mL}$ centrifuge tubes. To determine the contribution of suspended particulate matter to TA, one sample was left unfiltered, while the other was filtered through a $0.45 \mu \mathrm{m}$ nylon membrane syringe filter (Kim et al., 2006). TA was determined using the standard operating procedure for open cell potentiometric titration (Dickson et al., 2007; SOP 3b), using an automatic titrator (Metrohm 888 Titrando), a high-accuracy burette $(1 \pm 0.001 \mathrm{~mL})$, a thermostated reaction vessel $\left(T=25^{\circ} \mathrm{C}\right)$ and combination $\mathrm{pH}$ glass electrode (Metrohm 6.0259.100). TA values were calculated by a non-linear least-squares fit to the titration data in a custommade script in R. Quality assurance involved regular analysis of Certified Reference Materials (CRM) obtained from the Scripps Institution of Oceanography (A.G. Dickson, batches 116 and 122). The relative standard deviation of the procedure was less than $0.2 \%$ or $5 \mu \mathrm{mol} \mathrm{kg}{ }^{-1}(n=10)$.

Samples for DIC analysis were collected in $10 \mathrm{~mL}$ headspace vials, left to overflow and poisoned with $10 \mu \mathrm{L}$ of a saturated mercuric chloride $\left(\mathrm{HgCl}_{2}\right)$ solution. DIC analysis was performed using an AS-C3 analyser (Apollo SciTech) which consists of an acidification unit in combination with a LICOR LI-7000 $\mathrm{CO}_{2} / \mathrm{H}_{2} \mathrm{O}$ gas analyser. Quality assurance involved carrying out three replicate measurements of each sample and regular analysis of CRM. The accuracy and precision of the system are $0.15 \%$ or $3 \mu \mathrm{mol} \mathrm{kg}{ }^{-1}$.

Water for $p \mathrm{CO}_{2}$ analysis was collected in $50 \mathrm{~mL}$ glass serum bottles from the Niskin bottle with Tygon tubing, left to overflow, poisoned with $50 \mu \mathrm{L}$ of saturated $\mathrm{HgCl}_{2}$ and sealed with butyl stoppers and aluminium caps. Samples were analysed within 3 weeks of collection by the headspace technique (Weiss, 1981) using gas chromatography (GC) with a methaniser and flame ionisation detection (GC-FID, SRI 8610C). The GC-FID was calibrated with pure $\mathrm{N}_{2}$ and three $\mathrm{CO}_{2}: \mathrm{N}_{2}$ standards with a $\mathrm{CO}_{2}$ molar fraction of 404 , 1018, 3961 ppmv (Air Liquide Belgium). Headspace equilibration was done overnight in a thermostated bath, and temperature was recorded and typically within $3^{\circ} \mathrm{C}$ of in situ temperature. $p \mathrm{CO}_{2}$ data were corrected to in situ temperature. Samples were collected in duplicate and the relative standard deviation of duplicate analysis averaged $\pm 0.8 \%$ $(n=90)$.

Samples for the determination of $\mathrm{pH}$ were collected in $100 \mathrm{~mL}$ glass bottles. pH measurements were done immediately after collection at in situ temperature using a glass/reference electrode cell (Metrohm 6.0259.100) following standard procedures (Dickson et al., 2007; SOP 6a). Both National Institute of Standards and Technology (NIST) and TRIS (2-amino-2-hydroxymethyl-1,3-propanediol) buffers were used for calibration. The temperature difference between buffers and samples never exceeded $2{ }^{\circ} \mathrm{C}$. $\mathrm{pH}$ values are expressed on the total hydrogen ion scale $\left(\mathrm{pH}_{\mathrm{T}}\right)$.

\subsection{Community metabolism}

Net community respiration (NCP), gross primary production (GPP) and community respiration (CR) were determined using the oxygen light-dark method (Riley, 1939; Gazeau et al., 2005a). Samples were drawn from the Niskin bottle into similar BOD bottles as described in Sect. 2.2. Bottles were incubated on-deck in a water bath, keeping them at ambient 
surface-water temperature by continuous circulation of surface water. Samples were incubated both under various light intensities and in the dark. Hard neutral density filters with varying degrees of shading capacity (Lee Filters) were used to mimic light conditions at different depths, while sample bottles incubated in the dark were covered with aluminium foil. Incubations lasted from the time of sampling (usually mid-morning) until sunset. Oxygen concentrations were determined before and after incubation using the automated Winkler titration procedure described in Sect. 2.2.

Samples incubated in the light were used to determine $\mathrm{NCP}$ by calculating the difference in oxygen concentrations between the start and end of the incubations, divided by the incubation time ( 5 to $13 \mathrm{~h}$ ). CR was determined in a similar fashion from samples incubated in the dark. GPP was subsequently calculated as $\mathrm{NCP}+\mathrm{CR}$ (all rates expressed in mmol $\mathrm{O}_{2} \mathrm{~m}^{-3} \mathrm{~h}^{-1}$ ). To determine the relationship between algal biomass (represented as Chl $a$ concentration) and GPP, samples from all depths were incubated in triplicate at $51.2 \%$ of surface photosynthetically active radiation (PAR). This yielded a linear relationship between $[\mathrm{Chl} a]$ and GPP for most months (data not shown). Samples from one depth (typically $3 \mathrm{~m}$ ) were incubated at 10 different light intensities to determine the dependency of GPP on light availability $(P / I$ curve). These data were normalised to [Chl $a$ ] and fitted by non-linear least squares fitting using the Eilers-Peeters function (Eilers and Peeters, 1988):

$\mathrm{GPP}_{\text {norm }}=p_{\max } \frac{(2+\omega)\left(I / I_{\mathrm{opt}}\right)}{\left(I / I_{\mathrm{opt}}\right)^{2}+\omega\left(I / I_{\mathrm{opt}}\right)+1}$,

where $\mathrm{GPP}_{\text {norm }}$ is the measured GPP normalised to [Chl $a$ ] ( $\mathrm{mmol} \mathrm{O}_{2} \mathrm{mg} \mathrm{Chl} a^{-1} \mathrm{~h}^{-1}$ ), $p_{\max }$ is the maximum GPP ${ }_{\text {norm }}$

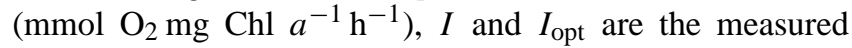
and optimum irradiance, respectively (both in $\mu \mathrm{mol}$ photons $\mathrm{m}^{-2} \mathrm{~s}^{-1}$ ) and $\omega$ is a dimensionless indicator of the relative magnitude of photoinhibition.

Downwelling light as a function of water depth was measured using a LI-COR LI-193SA spherical quantum sensor connected to a LI-COR LI-1000 data logger. A separate LICOR LI-190 quantum sensor on the roof of the research vessel connected to this data logger was used to correct for changes in incident irradiance. Light penetration depth (LPD; $1 \%$ of surface irradiance) was quantified by calculating the light attenuation coefficient using the LambertBeer extinction model. To additionally assess water-column transparency, Secchi disc depth was measured and corrected for solar altitude (Verschuur, 1997). In contrast to the measurements of downwelling irradiance, which were only taken mid-morning, Secchi depths were also determined in the afternoon. Although Secchi depths cannot directly be translated into LPD estimates, they do give an indication of the seasonal and diurnal variability in subsurface light climate.

Hourly averaged measurements of incident irradiance were obtained with a LI-COR LI-190SA quantum sensor from the roof of NIOZ-Yerseke, located about $31 \mathrm{~km}$ from the sampling site $\left(41.489^{\circ} \mathrm{N}, 4.057^{\circ} \mathrm{E}\right)$. These measurements, together with the light attenuation coefficient, were used to calculate the irradiance in the water column at each hour over the sampling day in $10 \mathrm{~cm}$ intervals until the LPD. Measured $[\mathrm{Chl} a]$ was linearly interpolated between sampling depths and combined with the fitted $P / I$ curve (Eq. 2) to calculate GPP ( $\left.\mathrm{mmol} \mathrm{O}_{2} \mathrm{~m}^{-3} \mathrm{~h}^{-1}\right)$ at $10 \mathrm{~cm}$ intervals:

$$
\mathrm{GPP}=[\mathrm{Chl} a] p_{\max } \frac{(2+\omega)\left(I / I_{\mathrm{opt}}\right)}{\left(I / I_{\mathrm{opt}}\right)^{2}+\omega\left(I / I_{\mathrm{opt}}\right)+1} .
$$

These GPP values were integrated over time to determine volumetric GPP on the day of sampling $\left(\mathrm{mmol} \mathrm{O}_{2} \mathrm{~m}^{-3} \mathrm{~d}^{-1}\right)$. A similar procedure using measured hourly incident irradiance was followed to calculate volumetric GPP on the days in between sampling days. Parameters of the Eilers-Peeters fit were kept constant in the monthly time interval around the day of sampling, while [Chl $a$ ] depth profiles and the light attenuation coefficient were linearly interpolated between time points. These daily GPP values were integrated over time to estimate annual GPP $\left(\mathrm{mmol} \mathrm{O}_{2} \mathrm{~m}^{-3} \mathrm{yr}^{-1}\right)$.

Rates of volumetric CR ( $\left.\mathrm{mmol} \mathrm{O}_{2} \mathrm{~m}^{-3} \mathrm{~h}^{-1}\right)$ were converted to daily values $\left(\mathrm{mmol} \mathrm{O}_{2} \mathrm{~m}^{-3} \mathrm{~d}^{-1}\right)$ by multiplying them by $24 \mathrm{~h}$. An annual estimate for CR (mmol $\mathrm{O}_{2} \mathrm{~m}^{-3} \mathrm{yr}^{-1}$ ) was calculated through linear interpolation of the daily $\mathrm{CR}$ values obtained on each sampling day. Finally, $\mathrm{CR}$ and GPP were converted from $\mathrm{O}_{2}$ to carbon (C) units. For CR, a respiratory quotient (RQ) of 1 was used. For GPP, the photosynthetic quotient (PQ) was based on the use of ammonium $\left(\mathrm{NH}_{4}^{+}\right)$or nitrate $\left(\mathrm{NO}_{3}^{-}\right)$during primary production. Assuming Redfield ratios, when $\mathrm{NH}_{4}^{+}$is taken up, this results in an $\mathrm{O}_{2}: \mathrm{C}$ ratio of $1: 1$, hence a PQ of 1 . Alternatively, when the algae use $\mathrm{NO}_{3}^{-}$, this leads to an $\mathrm{O}_{2}: \mathrm{C}$ ratio of $138: 106$ and a PQ of 1.3. Since the utilisation of $\mathrm{NH}_{4}^{+}$is energetically more favourable than that of $\mathrm{NO}_{3}^{-}$, the former is the preferred form of dissolved inorganic nitrogen taken up during primary production (e.g. MacIsaac and Dugdale, 1972). If $\left[\mathrm{NH}_{4}^{+}\right]<0.3 \mu \mathrm{mol} \mathrm{L}^{-1}$, we supposed that GPP was solely fuelled by $\mathrm{NO}_{3}^{-}$uptake, while above this threshold only $\mathrm{NH}_{4}^{+}$was assumed to be taken up during GPP. Although we are aware that this is a simplification of reality, as $\mathrm{NO}_{3}^{-}$ uptake is not completely inhibited at $\left[\mathrm{NH}_{4}^{+}\right]>0.3 \mu \mathrm{mol} \mathrm{L}{ }^{-1}$ (Dortch, 1990), we have no data to further distinguish between the two pathways. Concentrations of $\mathrm{NH}_{4}^{+}$and $\mathrm{NO}_{3}^{-}$ were determined in conjunction with concentrations of phosphate $\left(\mathrm{PO}_{4}^{3-}\right)$, silicate $\left(\mathrm{Si}(\mathrm{OH})_{4}\right)$ and nitrite $\left(\mathrm{NO}_{2}^{-}\right)$by automated colorimetric techniques (Middelburg and Nieuwenhuize, 2000) after filtration through $0.2 \mu \mathrm{m}$ filters. Water for DOC analysis was collected in $10 \mathrm{~mL}$ glass vials and filtered over pre-combusted Whatman GF/F filters $(0.7 \mu \mathrm{m})$. Samples were analysed using a Formacs Skalar-04 by automated UVwet oxidation to $\mathrm{CO}_{2}$, which concentration is subsequently measured with a non-dispersive infrared detector (Middelburg and Herman, 2007). Nutrient and DOC data can be found in the Supplement. 


\subsection{Sediment fluxes}

To determine DIC and TA fluxes across the sediment-water interface, we used shipboard closed-chamber incubations. Upon sediment core retrieval, the water level was adjusted to ca. $18-20 \mathrm{~cm}$ above the sediment surface. To mimic in situ conditions, the overlying water was replaced with ambient bottom water prior to the start of the incubations, using a gastight tube and ensuring minimal disturbance of the sedimentwater interface. Immediately thereafter, the cores were sealed with gas-tight polyoxymethylene lids and transferred to a temperature-controlled container set at in situ temperature. The core lids contained two sampling ports on opposite sides and a central stirrer to ensure that the overlying water remained well mixed. Incubations were done in triplicate and the incubation time was determined in such a way that during incubation the concentration change of DIC would remain linear. As a result, incubation times varied from 6 (at $\mathrm{S} 1$ during summer) to $65 \mathrm{~h}$ (at S3 during winter).

Throughout the incubation, water samples $(\sim 7 \mathrm{~mL})$ for DIC analysis were collected from each core five times at regular time intervals in glass syringes via one of the sampling ports. Concurrently, an equal amount of ambient bottom water was added through a replacement tube attached to the other sampling port. About $5 \mathrm{~mL}$ of the sample was transferred to a headspace vial, poisoned with $5 \mu \mathrm{L}$ of a saturated $\mathrm{HgCl}_{2}$ solution and stored submerged at $4{ }^{\circ} \mathrm{C}$. These samples were analysed as described in Sect. 2.3. The subsampling volume of $7 \mathrm{~mL}$ was less than $5 \%$ of the water mass, so no correction factor was applied to account for dilution. DIC fluxes (mmol m $\mathrm{m}^{-2} \mathrm{~d}^{-1}$ ) were calculated from the change in concentration, taking into account the enclosed sediment area and overlying water volume:

$J=\left(\frac{\Delta C_{\mathrm{ow}}}{\Delta t}\right) \frac{V_{\mathrm{ow}}}{A}$,

where $\frac{\Delta C_{\mathrm{ow}}}{\Delta t}$ is the change in DIC in the overlying water vs. time $\left(\mathrm{mmol} \mathrm{m}^{-3} \mathrm{~d}^{-1}\right)$, which was calculated from the five data points by linear regression, $\mathrm{V}_{\mathrm{ow}}$ is the volume of the overlying water $\left(\mathrm{m}^{3}\right)$ and $A$ is the sediment surface area $\left(\mathrm{m}^{2}\right)$. To determine TA fluxes, no subsampling was performed. Instead, the fluxes were calculated from the difference in TA between the beginning and end of the incubation, accounting for enclosed sediment area and overlying water volume. TA samples were collected and analysed as described in Sect. 2.3.

\subsection{Carbonate system calculations}

The measurement of four carbonate system parameters implies that we can check the internal consistency of the carbonate system (see Appendix A). For the rest of this paper, we use DIC and $\mathrm{pH}_{\mathrm{T}}$ for the carbonate system calculations. This has been suggested to be the best choice when systems other than the open ocean are studied and measurements of
TA may be difficult to interpret (Dickson, 2010; see also Appendix A). All calculations were performed using the $\mathrm{R}$ package AquaEnv. The main advantage of AquaEnv is that it has the possibility to include acid-base systems other than the carbonate and borate system, which is especially important in highly productive and hypoxic waters. Furthermore, it provides a suite of output parameters necessary to compute the individual impact of a process on $\mathrm{pH}$, such as the acidbase buffering capacity. As equilibrium constants for the carbonate system we used those of Mehrbach et al. (1973) as refitted by Dickson and Millero (1987), which were calculated from CTD-derived $T, S$ and $p$ using CO2SYS (Pierrot et al., 2006). For the other equilibrium constants (borate, phosphate, ammonia, silicate, nitrite, nitrate and the auto-dissociation of water) we chose the default settings of AquaEnv.

$\mathrm{CO}_{2}$ air-sea exchange $\left(\mathrm{mmol} \mathrm{C} \mathrm{m}{ }^{-2} \mathrm{~d}^{-1}\right.$ ) on the day of sampling was estimated using the gradient between atmospheric $p \mathrm{CO}_{2}\left(p \mathrm{CO}_{2, \text { atm }}\right)$ and the calculated seawater $p \mathrm{CO}_{2}$ at $1 \mathrm{~m}$ depth (both in atm):

$F=k \alpha\left(p \mathrm{CO}_{2}-p \mathrm{CO}_{2, \mathrm{~atm}}\right)$,

where $k\left(\mathrm{md}^{-1}\right)$ is the gas transfer velocity, which was calculated from wind speed according to Wanninkhof (1992), normalised to a Schmidt number of 660 . Daily-averaged wind speed at Wilhelminadorp $\left(51.527^{\circ} \mathrm{N}, 3.884^{\circ} \mathrm{E}\right.$, measured at $10 \mathrm{~m}$ above the surface) was obtained from the Royal Netherlands Meteorological Institute (http://www.knmi.nl). The quantity $\alpha$ is the solubility of $\mathrm{CO}_{2}$ in seawater (Henry's constant; $\mathrm{mmol} \mathrm{m}^{-3} \mathrm{~atm}^{-1}$ ) and was calculated according to Weiss (1974). For $p \mathrm{CO}_{2}$,atm we used monthly mean values measured at Mace Head $\left(53.326^{\circ} \mathrm{N}, 9.899^{\circ}\right.$,W) as obtained from the National Oceanic and Atmospheric Administration Climate Monitoring and Diagnostics Laboratory air sampling network (http://www.cmdl.noaa.gov/). To calculate $\mathrm{CO}_{2}$ air-sea exchange on the days between sampling days, we used daily-averaged wind speed and linear interpolation of the other parameters.

\subsection{Acid-base buffering capacity and proton cycling}

The acid-base buffering capacity plays a crucial role in the $\mathrm{pH}$ dynamics of natural waters. Many different formulations of this buffering capacity exist (Frankignoulle, 1994; Egleston et al., 2010). However, a recent theoretical analysis (Hofmann et al., 2008) has shown that, for natural waters, it is most adequately defined as the change in TA associated with a certain change in $\left[\mathrm{H}^{+}\right]$, thereby keeping all other total concentrations (e.g. DIC, total borate) constant:

$\beta=-\left(\frac{\partial \mathrm{TA}}{\partial\left[\mathrm{H}^{+}\right]}\right)$.

Hence, when the acid-base buffering capacity of the water is high, one will observe only a small change in $\left[\mathrm{H}^{+}\right]$for 
a given change in TA. It should be noted that $\beta$ is intrinsically different from the well-known Revelle factor (Revelle and Suess, 1957; Sundquist et al., 1979) that quantifies the $\mathrm{CO}_{2}$ buffering capacity of seawater, i.e. the resilience of the coupled ocean-atmosphere system towards a perturbation in atmospheric $\mathrm{CO}_{2}$.

In this study, $\beta$ was calculated according to Hofmann et al. (2008) and subsequently used to quantify the effect of several processes on $\mathrm{pH}$ individually as described in Hofmann et al. (2010a). Traditionally, the carbonate system is quantified using DIC and TA. Although this approach has many advantages, it can only determine the combined effect of several concomitantly acting processes on $\mathrm{pH}$. In the method proposed by Hofmann et al. (2010a), pH is calculated explicitly in conjunction with DIC. As a result, the individual contribution of each individual process on $\mathrm{pH}$ can be extracted, even though several processes are acting simultaneously (Hagens et al., 2014). Therefore, this method is ideally suited for the analysis of proton cycling and constructing proton budgets. Briefly, each chemical reaction takes place at a certain rate and with a certain stoichiometry; for example, aerobic respiration can be described as

$$
\begin{aligned}
& \mathrm{CH}_{2} \mathrm{O}\left(\mathrm{NH}_{3}\right)_{\gamma_{\mathrm{N}}}\left(\mathrm{H}_{3} \mathrm{PO}_{4}\right)_{\gamma_{\mathrm{P}}}+\mathrm{O}_{2} \rightarrow \mathrm{CO}_{2}+\mathrm{H}_{2} \mathrm{O} \\
& +\gamma_{\mathrm{N}} \mathrm{NH}_{3}+\gamma_{\mathrm{P}} \mathrm{H}_{3} \mathrm{PO}_{4},
\end{aligned}
$$

where $\gamma_{\mathrm{N}}$ and $\gamma_{\mathrm{P}}$ are the ratios of nitrogen $(\mathrm{N})$ and phosphorus $(\mathrm{P})$ to carbon $(\mathrm{C})$ in organic matter, respectively. At first sight, this reaction equation does not seem to produce any protons. However, the $\mathrm{CO}_{2}$ (as carbonic acid, $\mathrm{H}_{2} \mathrm{CO}_{3}$ ), ammonia $\left(\mathrm{NH}_{3}\right)$ and phosphoric acid $\left(\mathrm{H}_{3} \mathrm{PO}_{4}\right)$ formed will immediately dissociate into other forms at a ratio similar to their occurrence at ambient $\mathrm{pH}$. As a result, protons are produced during aerobic respiration, despite the fact they are absent in Eq. (R1). The amount of protons produced is termed the stoichiometric coefficient for the proton $\left(v_{\mathrm{H}^{+}}^{x}\right)$ or proton release rate. This coefficient is process-specific and, for aerobic respiration, equals $c_{2}+2 c_{3}-\gamma_{\mathrm{N}} n_{1}+\gamma_{\mathrm{P}}\left(p_{2}+2 p_{3}+3 p_{4}\right)$ (Hofmann et al., 2010a; Table 1). Here, $c_{2}$ and $c_{3}$ are the ratios of bicarbonate $\left(\mathrm{HCO}_{3}^{-}\right)$and carbonate $\left(\mathrm{CO}_{3}^{2-}\right)$ to DIC, $n_{1}$ is the ratio of $\mathrm{NH}_{4}^{+}$to total ammonia, and $p_{2}, p_{3}$ and $p_{4}$ are the ratios of dihydrogen phosphate $\left(\mathrm{H}_{2} \mathrm{PO}_{4}^{-}\right)$, monohydrogen phosphate $\left(\mathrm{HPO}_{4}^{2-}\right)$ and $\mathrm{PO}_{4}^{3-}$ to total phosphate, respectively. As these ratios depend on the ambient $\mathrm{pH}$, so does the value of $v_{\mathrm{H}^{+}}^{x}$.

In natural systems, the vast majority of protons produced during a biogeochemical process according to $v_{\mathrm{H}^{+}}^{x}$ are consumed through immediate acid-base reactions, thereby neutralising their acidifying effect. The extent to which this attenuation occurs is controlled by the acid-base buffering capacity of the system. Hence, the net change in $\left[\mathrm{H}^{+}\right]$due to a certain process $x\left(\mu \mathrm{mol} \mathrm{kg}{ }^{-1} \mathrm{~d}^{-1}\right)$ is the product of the process rate $\left(R_{x} ; \mu \mathrm{mol} \mathrm{kg}^{-1} \mathrm{~d}^{-1}\right)$ and the stoichiometric coeffi- cient for the proton of that reaction $\left(v_{\mathrm{H}^{+}}^{x}\right)$, divided by $\beta$ :

$\frac{\mathrm{d}\left[\mathrm{H}^{+}\right]_{x}}{\mathrm{~d} t}=\frac{v_{\mathrm{H}^{+}}^{x}}{\beta} R_{x}$.

The total net change in $\left[\mathrm{H}^{+}\right]$over time is simply the sum of the effects of all relevant processes, as they occur simultaneously:

$\frac{\mathrm{d}\left[\mathrm{H}^{+}\right]_{\mathrm{tot}}}{\mathrm{d} t}=\frac{1}{\beta} \sum_{x=1}^{n} v_{\mathrm{H}^{+}}^{x} R_{x}$.

A straightforward way to express the vulnerability of a system to changes in $\mathrm{pH}$ is to look at the proton turnover time (Hofmann et al., 2010a). For this we first need to define the proton cycling intensity, which is the sum of all proton-producing (or consuming) processes. When dividing the ambient $\left[\mathrm{H}^{+}\right]$by the proton cycling intensity, the proton turnover time $\left(\tau_{\mathrm{H}^{+}}\right)$can be estimated. The smaller the proton turnover time, the more susceptible the system is to changes in $\mathrm{pH}$. In a system that is in steady state, i.e. the final change in $\left[\mathrm{H}^{+}\right]$is zero, the proton cycling intensity is the same irrespective of whether the sum of the proton producing or consuming processes is used for its calculation. In a natural system like the Den Osse basin this is not the case, meaning that total $\mathrm{H}^{+}$production and total $\mathrm{H}^{+}$consumption are not equal. Here, we use the smaller of the two for the calculation of the proton cycling intensity. As a result, the calculated turnover times should be regarded as maximal values.

\subsection{Proton budget calculations}

Figure 2 shows a schematic overview of the major processes affecting proton cycling in the Den Osse basin. For each of the four seasons (March, May, August and November), we estimated a proton budget for the basin by calculating the net production of protons $\left(\frac{\mathrm{d}\left[\mathrm{H}^{+}\right]_{x}}{\mathrm{~d} t}\right)$ for GPP, CR, nitrification, $\mathrm{CO}_{2}$ air-sea exchange, sediment-water exchange of DIC and TA and vertical water-column mixing, taking account of the effects of S and T changes (Hofmann et al., 2008, 2009). These budgets thus represent the processes influencing the cycling of protons on the day of sampling. We divided the vertical of the basin into eight depth layers, whereby the eight sampling depths represented the midpoint of each layer. Using the bathymetry of the lake, for each box we calculated the total volume of water in the layer, the area at the upper and lower boundary (planar area) and the sediment area interfacing each box. The stoichiometric coefficients for the proton $\left(v_{\mathrm{H}^{+}}^{x}\right)$ were calculated with AquaEnv using the measured concentrations of DIC, total phosphate, total ammonia and total nitrate (Table 1). Rates of nitrification (mmol $\mathrm{N} \mathrm{m}^{-3} \mathrm{~d}^{-1}$ ) were estimated from the measured $T$, $\left[\mathrm{NH}_{4}^{+}\right]$and 
Table 1. Stoichiometric coefficients for the proton $\left(v_{\mathrm{H}^{+}}^{x}\right)$ for each reaction considered in the proton budget. $c_{2}$ and $c_{3}$ are the ratios of $\mathrm{HCO}_{3}^{-}$ and $\mathrm{CO}_{3}^{2-}$ to $\mathrm{DIC}, \mathrm{na}_{1}$ and na 2 are the ratios of $\mathrm{HNO}_{3}$ and $\mathrm{NO}_{3}^{-}$to total nitrate, $\mathrm{n}_{1}$ is the ratio of $\mathrm{NH}_{4}^{+}$to total ammonia, and $p_{2}, p_{3}$ and $p_{4}$ are the ratios of $\mathrm{H}_{2} \mathrm{PO}_{4}^{-}, \mathrm{HPO}_{4}^{2-}$ and $\mathrm{PO}_{4}^{3-}$ to total phosphate, respectively.

\begin{tabular}{lll}
\hline Process $x$ & $v_{\mathrm{H}^{+}}^{x}$ & Range in 2012 \\
\hline GPP $\left(\mathrm{N}\right.$-source $\left.=\mathrm{NH}_{4}^{+}\right)$ & $-c_{2}-2 c_{3}+\gamma_{\mathrm{N}} n_{1}-\gamma_{\mathrm{P}}\left(p_{2}+2 p_{3}+3 p_{4}\right)$ & -1.01 to -0.88 \\
GPP $\left(\mathrm{N}\right.$-source $\left.=\mathrm{NO}_{3}^{-}\right)$ & $-c_{2}-2 c_{3}-\gamma_{\mathrm{N} n a_{2}}-\gamma_{\mathrm{P}}\left(p_{2}+2 p_{3}+3 p_{4}\right)$ & -1.31 to -1.18 \\
$\mathrm{CR}$ & $c_{2}+2 c_{3}-\gamma_{\mathrm{N}} n_{1}+\gamma_{\mathrm{P}}\left(p_{2}+2 p_{3}+3 p_{4}\right)$ & 0.88 to 1.01 \\
Nitrification & $2-n_{2}-\mathrm{na}_{1}$ & 1.93 to 1.99 \\
$\mathrm{CO}_{2}$ sea-air exchange & $c_{2}+2 c_{3}$ & 1.01 to 1.13 \\
Transport/sediment efflux of TA & -1 & - \\
Transport/sediment efflux of DIC & $\frac{\partial \mathrm{TA}}{\partial \mathrm{DIC}}$ & 1.01 to 1.13 \\
\hline
\end{tabular}

$\left[\mathrm{O}_{2}\right]$ (in mmol $\mathrm{m}^{-3}$ ) using (Regnier et al., 1997):

$R_{\text {nitr }}=86400 k_{\max } \exp \left(\frac{T-20}{10} \ln \left(q_{10}\right)\right)$

$\frac{\left[\mathrm{NH}_{4}^{+}\right]}{\left[\mathrm{NH}_{4}^{+}\right]+250} \frac{\left[\mathrm{O}_{2}\right]}{\left[\mathrm{O}_{2}\right]+15}$,

where $k_{\max }$ is the maximum nitrification rate constant $\left(3 \times 10^{-4} \mathrm{mmol} \mathrm{m}^{-3} \mathrm{~s}^{-1}\right)$ and $q_{10}$, which is set at 2 , is the factor of change in rate for a change in temperature of $10^{\circ} \mathrm{C} . \mathrm{CO}_{2}$ air-sea exchange rates were converted to mmol m${ }^{-3} \mathrm{~d}^{-1}$ by first multiplying them with the total surface area of the Den Osse basin $\left(\mathrm{m}^{2}\right)$ and then dividing them by the volume of the uppermost box $\left(\mathrm{m}^{3}\right)$, assuming that $\mathrm{CO}_{2}$ air-sea exchange only directly affects the proton budget of this box. Similarly, DIC and TA sediment fluxes $\left(\mathrm{mmol} \mathrm{m} \mathrm{m}^{-2} \mathrm{~d}^{-1}\right.$ ) were multiplied by the corresponding sediment area of the basin $\left(\mathrm{m}^{2}\right)$ and then divided by the volume of the box corresponding to their measurement depth $\left(\mathrm{m}^{3}\right)$. To ensure mass conservation, vertical TA and DIC transport rates $\left(\mathrm{mmol} \mathrm{d}^{-1}\right)$ were computed by multiplying the difference in mass between two consecutive boxes (mmol), i.e. the product of concentration and volume, with a mixing coefficient $\zeta\left(\mathrm{d}^{-1}\right)$ that was calculated based on the entrainment function by Pieters et al. (1985), multiplied by the volume of water below the pycnocline. Then the transport rates were converted to $\mathrm{mmol} \mathrm{m}^{-3} \mathrm{~d}^{-1}$ by dividing them by the volume of the corresponding box. Finally, all rates (expressed in $\left.\mathrm{mmol} \mathrm{m} \mathrm{m}^{-3} \mathrm{~d}^{-1}\right)$ were divided by $10^{-3} \times \rho_{\mathrm{w}}\left(\mathrm{kg} \mathrm{L}^{-1}\right)$ to convert them to $\mu \mathrm{mol} \mathrm{kg} \mathrm{kg}^{-1} \mathrm{~d}^{-1}$.

The sum of $\frac{\mathrm{d}\left[\mathrm{H}^{+}\right]_{x}}{\mathrm{~d} t}$ of all processes considered $\left(\frac{\mathrm{d}\left[\mathrm{H}^{+} \text {tot }\right.}{\mathrm{d} t}\right.$; Eq. 8) was compared with $\frac{\Delta\left[\mathrm{H}^{+}\right]_{\mathrm{obs}}}{\Delta t}$, which was calculated from the measured $\mathrm{pH}_{\mathrm{T}}$ as the weighted average of the observed change in $\left[\mathrm{H}^{+}\right]$between the previous month and the current month, and between the current month and the next month. The difference between $\frac{\Delta\left[\mathrm{H}^{+}\right]_{\text {obs }}}{\Delta t}$ and $\frac{\mathrm{d}\left[\mathrm{H}^{+}\right]_{\text {tot }}}{\mathrm{d} t}$ is represented as the closure term of the budget, which is needed because some of the proton producing and consuming processes are unknown or have not been measured. This budget closure term includes the effect of lateral transport induced by wind and/or water entering Lake Grevelingen through the seaward sluice, which could not be quantified due to a lack of hydrodynamic data.

\section{Results}

\subsection{Environmental settings}

Over the year 2012, the surface-water temperature at Den Osse ranged from 1.99 to $21.03^{\circ} \mathrm{C}$, while bottom-water temperature showed a substantially smaller variation (1.47$16.86^{\circ} \mathrm{C}$; Fig. 3a). The surface water was colder than the bottom water in January, while the reverse was true between February and April. However, the temperature difference between surface and bottom water of Den Osse remained within $1^{\circ} \mathrm{C}$. Warming of the surface water in late spring rapidly increased the difference between surface and bottom water to $9.3^{\circ} \mathrm{C}$ in May. This surface-to-bottom difference in temperature decreased but persisted until August. The thermocline, which was located between 10 and $15 \mathrm{~m}$ in May, deepened to 15-20 $\mathrm{m}$ in June. In July and August, on the contrary, temperature continuously decreased with depth. In September, the temperature depth profile was almost homogeneous, while in November and December surface waters were again cooler than bottom waters.

Salinity (Fig. 3b) increased with water depth at all months, but the depth of the halocline and the magnitude of the salinity gradient varied considerably over the year. This salinity gradient resulted from denser, more saline North Sea water that sank when entering Lake Grevelingen. Variations in the sluice operation, and resulting changes in North Sea exchange volumes, could therefore explain the observed month-to-month variability in salinity depth profiles. Halocline depth varied between ca. $6 \mathrm{~m}$ (March and from August to October) to ca. $17 \mathrm{~m}$ (November). The largest difference between surface (30.08) and bottom (32.21) water salinity was found in March. Lower inflow and outflow volumes, resulting from strict water level regulations in spring and early 
summer (Wetsteyn, 2011), led to a lower salinity throughout the water column between April and June. In July and August, a small $(\sim 0.2)$ but noticeable decrease in salinity was recorded from 15-20 m onwards, suggesting the intrusion of a different water mass. Precipitation did not appear to exert a major control on the salinity distribution, as there was no correlation between mean water-column salinity and monthly rainfall as calculated from daily-integrated rainfall data obtained from the Royal Netherlands Meteorological Institute (http://www.knmi.nl) measured at Wilhelminadorp.

Similar to temperature, the difference in density anomaly $\left(\sigma_{\mathrm{T}}\right.$; Fig. 3c) between surface and deep water was highest in May. This density gradient was sustained until August, indicating strong water-column stratification during this period. The depth of the pycnocline decreased from ca. $15 \mathrm{~m}$ in May and June to ca. $10 \mathrm{~m}$ in July and August. This corresponded to a weakening of the stratification as indicated by the stratification parameter $\phi$, which dropped from $3.34 \mathrm{~J} \mathrm{~m}^{-3}$ in May to $2.09 \mathrm{~J} \mathrm{~m}^{-3}$ in August (Fig. 3e). This weakening in stratification was presumably due to the delayed warming of bottom water compared to surface water. A week before sampling in September, weather conditions were stormy (maximum daily-averaged wind speed of $7.0 \mathrm{~m} \mathrm{~s}^{-1}$ ), which most likely disrupted stratification and led to ventilation of the bottom water. The resemblance in the spatio-temporal patterns of $T$, $S$ and $\sigma_{\mathrm{T}}$ indicates that the water-column stratification was controlled by both temperature and salinity, where salinity was important in winter ( $\phi$ values of ca. $1 \mathrm{~J} \mathrm{~m}^{-3}$ ) and temperature gradients intensified stratification in late spring and summer.

Oxygen concentrations (Fig. 3d) were highest in February as a result of the low water temperatures, increasing $\mathrm{O}_{2}$ solubility. A second peak in $\left[\mathrm{O}_{2}\right]$ occurred in the surface water in July, during a period of high primary production (see Sect. 3.3.1), and led to $\mathrm{O}_{2}$ oversaturation in the upper metres. From late spring onwards, water-column stratification led to a steady decline in $\left[\mathrm{O}_{2}\right]$ below the mixed-layer depth, resulting in hypoxic conditions $\left(<62.5 \mu \mathrm{mol} \mathrm{L}^{-1}\right)$ below the pycnocline in July and August. Although in August the bottom water was fully depleted of $\mathrm{O}_{2},\left[\mathrm{H}_{2} \mathrm{~S}\right]$ remained below the detection limit $(5 \mu \mathrm{M})$, indicating the absence of euxinia. From September onwards, water-column mixing restored high $\mathrm{O}_{2}$ concentrations throughout the water column.

Lake Grevelingen surface water is generally characterised by high water transparency and deep light penetration (Fig. 3e). LPD was $9.4 \mathrm{~m}$ in March and slightly increased to $10.6 \mathrm{~m}$ in May. Between June and August, during a period of high primary production (see Sect. 3.3.1), LPD decreased until $5.8 \mathrm{~m}$. From September onwards, the surface water turned more transparent again. Accordingly, LPD increased up to $12.6 \mathrm{~m}$ in November, after which it stabilised at a value of $12.0 \mathrm{~m}$ in December. The Secchi disc data generally confirm the observed temporal pattern in the LPD, as is shown by the significant correlation between morning Secchi depths and LPD $\left(r^{2}=0.86 ; P<0.001\right)$. Secchi disc depth

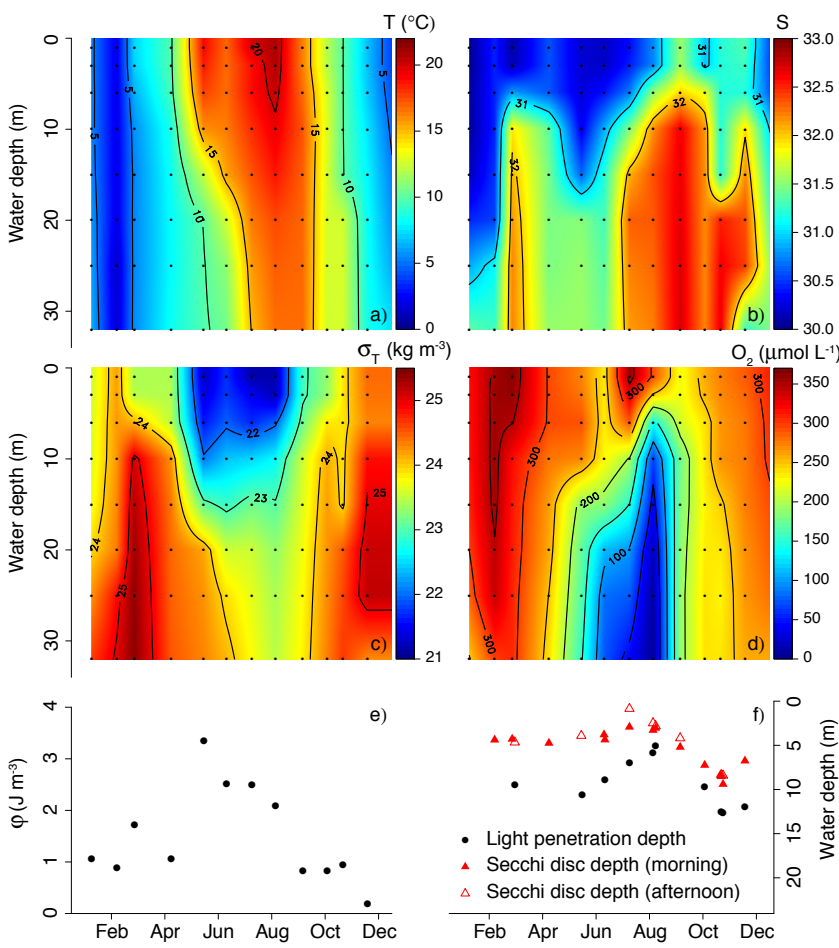

Figure 3. (a) Temperature $\left({ }^{\circ} \mathrm{C}\right)$, (b) salinity, (c) density anomaly $\left(\mathrm{kg} \mathrm{m}^{-3}\right)$, (d) $\mathrm{O}_{2}\left(\mu \mathrm{mol} \mathrm{L}^{-1}\right)$, (e) stratification parameter $\phi\left(\mathrm{J} \mathrm{m}^{-3}\right)$ and (f) light penetration and Secchi disc depths at the Den Osse basin in 2012. Black dots in (a-d) indicate measurements. Data from (a-d) were linearly interpolated in space and time.

was on average $\sim 80 \%$ of LPD and, similar to LPD, was highest in November and lowest in July. Additionally, the Secchi depths indicate that diurnal variations in light penetration may exist. Especially in July, during an intense dinoflagellate bloom (see Sect. 3.3.1), light penetrated much deeper into the water column in the morning than in the afternoon (Secchi disc depths of 2.9 and $0.9 \mathrm{~m}$, respectively). The difference between morning and afternoon Secchi disc depth was much smaller in August (3.3 and $2.5 \mathrm{~m}$ ) and virtually absent in November (8.5 and $8.4 \mathrm{~m})$.

\subsection{Carbonate system variability}

\subsection{1 $\mathrm{pH}_{\mathrm{T}}, \mathrm{DIC}, \mathrm{TA}, p \mathrm{CO}_{2}$}

In January, $\mathrm{pH}_{\mathrm{T}}$ showed little variation with depth, with an average value of 8.04 (Fig. 4a). From February to April, $\mathrm{pH}_{\mathrm{T}}$ increased throughout the water column, though the increase was faster at the surface than at depth, up to a maximum of 8.36 in the surface water in April. From June onwards, stratification augmented the difference between surface and bottom water $\mathrm{pH}_{\mathrm{T}}$. In August, this difference had increased to 0.69 units. The sharp decrease in $\mathrm{pH}_{\mathrm{T}}$ with depth during this month coincided with the declining trend seen for $\left[\mathrm{O}_{2}\right]$ (Fig. 3d), highlighting the connection between bottom-water 


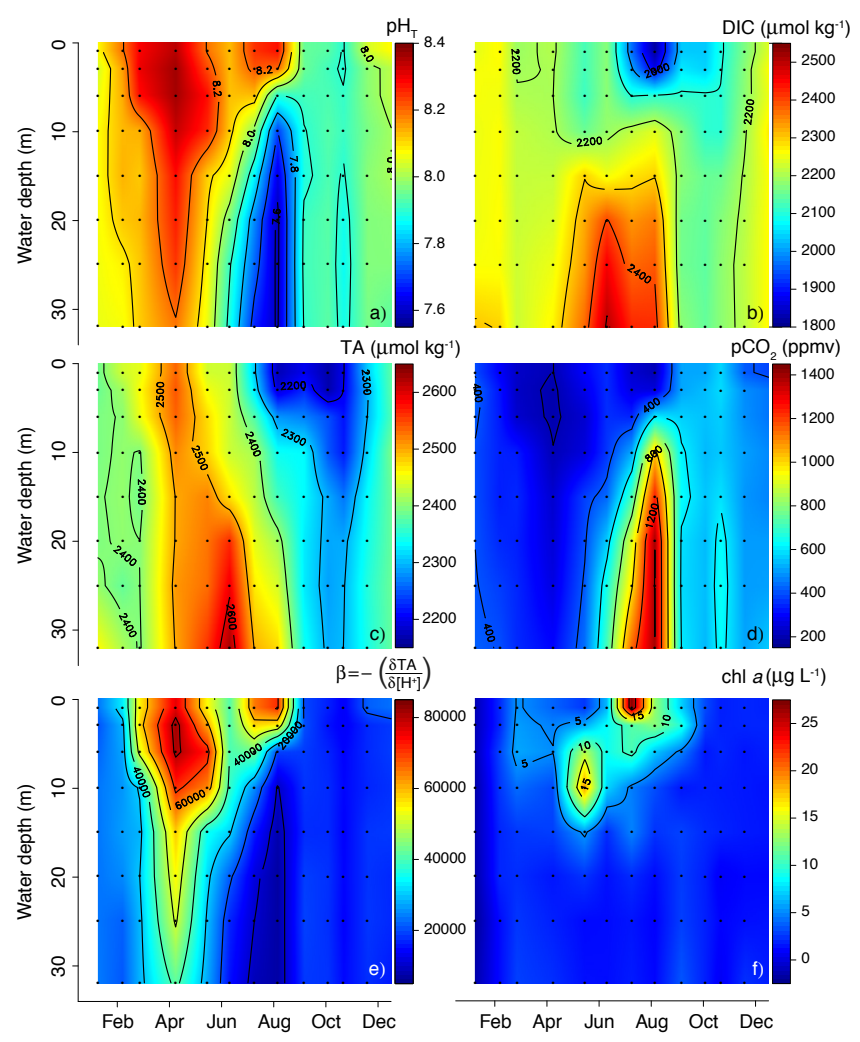

Figure 4. (a) $\mathrm{pH}_{\mathrm{T}}$ (at in situ temperature), (b) $\mathrm{DIC}\left(\mu \mathrm{mol} \mathrm{kg}{ }^{-1}\right)$, (c) $\mathrm{TA}\left(\mu \mathrm{mol} \mathrm{kg}{ }^{-1}\right)$, (d) $p \mathrm{CO}_{2}$ (ppmv), (e) buffering capacity $(\beta)$ and (f) concentration of Chl $a\left(\mu \mathrm{g} \mathrm{L}^{-1}\right)$ at Den Osse in 2012. Black dots indicate sampling intervals. TA and $p \mathrm{CO}_{2}$ were calculated from measured $\mathrm{pH}_{\mathrm{T}}$ and DIC using the equilibrium constants of Mehrbach et al. (1973) as refitted by Dickson and Millero (1987), while $\beta$ was calculated from measured $\mathrm{pH}_{\mathrm{T}}$ and calculated TA. All data were linearly interpolated in space and time.

$\mathrm{pH}$ and low $\left[\mathrm{O}_{2}\right]$ in seasonally stratified waters. Additionally, elevated surface water $\mathrm{pH}_{\mathrm{T}}$ in summer co-occurred with high $\left[\mathrm{O}_{2}\right]$, concurrent with an intense dinoflagellate bloom (see Sect. 3.3.1). Similar to the depth profiles of $\left[\mathrm{O}_{2}\right]$, the termination of stratification diminished the gradient between surface and bottom-water $\mathrm{pH}_{\mathrm{T}}$. However, $\mathrm{pH}_{\mathrm{T}}$ at the end of 2012 was significantly lower (average value of 7.98 ) than at the beginning of 2012. Over the year, surface-water $\mathrm{pH}_{\mathrm{T}}$ varied 0.46 units, while bottom-water $\mathrm{pH}_{\mathrm{T}}$ variation was higher (0.60 units).

DIC (Fig. 4b) showed little variation with depth in January and February (average value $2257 \mu \mathrm{mol} \mathrm{kg}^{-1}$ ), with the exception of the bottom water, where DIC was slightly (40$50 \mu \mathrm{mol} \mathrm{kg}{ }^{-1}$ ) elevated. In March, DIC decreased slightly throughout the water column, with a stronger drawdown in the upper $6-10 \mathrm{~m}$, and the higher bottom-water concentrations diminished. The difference between surface and deeper water increased until ca. $70 \mu \mathrm{mol} \mathrm{kg}{ }^{-1}$ in April, due to an increase in bottom-water DIC. In May, a concurrent drawdown in DIC above $15 \mathrm{~m}$ and increase in DIC below this depth resulted in a surface-to-bottom DIC difference of $250 \mu \mathrm{mol} \mathrm{kg}{ }^{-1}$. The depth of this sharp transition coincided with the pycnocline depth. In June, DIC increased strongly (by $100-200 \mu \mathrm{mol} \mathrm{kg}{ }^{-1}$ ) below the pycnocline, while in July and August, a strong drawdown in DIC occurred above the pycnocline, concurrent with an intense dinoflagellate bloom (see Sect. 3.3.1). In combination with the persisting stratification, this resulted in a surface-to-bottom difference in DIC of $600 \mu \mathrm{mol} \mathrm{kg}{ }^{-1}$. After the disruption of the stratification, the difference between surface and bottom water DIC was greatly reduced, and decreased further from 144 to $47 \mu \mathrm{mol} \mathrm{kg}{ }^{-1}$ between September and December. Concomitantly, the average DIC increased from 2146 to $2201 \mu \mathrm{mol} \mathrm{kg}{ }^{-1}$, although the month of October was characterised by overall slightly lower DIC (average value of $\left.2123 \mu \mathrm{mol} \mathrm{kg}^{-1}\right)$. Surface-water DIC variation over the year $\left(453 \mu \mathrm{mol} \mathrm{kg}{ }^{-1}\right)$ was somewhat higher than in the bottom water $\left(361 \mu \mathrm{mol} \mathrm{kg}{ }^{-1}\right)$.

TA (Fig. 4c) generally showed more temporal than spatial variability. Therefore, variations in TA with depth were usually much smaller compared to DIC. In January and February, TA was fairly constant with depth (average value of $2404 \mu \mathrm{mol} \mathrm{kg}^{-1}$ ), with the exception of bottom-water TA in January $\left(2460 \mu \mathrm{mol} \mathrm{kg}{ }^{-1}\right)$. In March and April, TA in the upper $6 \mathrm{~m}$ was $40-50 \mu \mathrm{mol} \mathrm{kg}{ }^{-1}$ higher than in the underlying water. Overall, TA in April had increased by on average $105 \mu \mathrm{mol} \mathrm{kg}-1$ compared to March. The period of water-column stratification was characterised by a positive surface-to-bottom-water TA difference correlating with pycnocline depth. This difference was highest in June $\left(195 \mu \mathrm{mol} \mathrm{kg}{ }^{-1}\right)$, as a result of high bottom-water TA, and in August ( $306 \mu \mathrm{mol} \mathrm{kg}^{-1}$ ), mainly due to the strong drawdown in surface-water TA. Because of this, average water-column $\mathrm{TA}$ in June was much higher $\left(2520 \mu \mathrm{mol} \mathrm{kg}{ }^{-1}\right)$ than in August $\left(2366 \mu \mathrm{mol} \mathrm{kg}{ }^{-1}\right)$. The low surface-water TA persisted until November, while TA below $10 \mathrm{~m}$ depth was much less variable. Similar to DIC, the month of October was characterised by overall lower TA. There was little difference between surface- and bottom-water variation in TA over the entire year (372 and $337 \mu \mathrm{mol} \mathrm{kg}{ }^{-1}$, respectively).

The pattern of $p \mathrm{CO}_{2}$ (Fig. 4d) was inversely proportional to that of $\mathrm{pH}_{\mathrm{T}}$. January was characterised by little variation with depth and an average $p \mathrm{CO}_{2}$ (404 ppmv) close to $p \mathrm{CO}_{2, \text { atm }}$ (396 ppmv). In February, low $\mathrm{T}$ throughout the water column led to a drawdown of $p \mathrm{CO}_{2}$ which continued until April, albeit with larger magnitude in the surface compared to the bottom water. The onset of stratification in May led to a build-up of $\mathrm{CO}_{2}$ resulting from organic matter degradation in the bottom water. Maximum bottomwater $p \mathrm{CO}_{2}$ (1399 ppmv) was found in August and, as expected, co-occurred with the period of most intense hypoxia (Fig. 3d). While in May and June, $p \mathrm{CO}_{2}$ increased throughout the water column, in July and August a substantial drawdown in surface-water $p \mathrm{CO}_{2}$ was observed coinciding with an increase in $\left[\mathrm{O}_{2}\right]$, which is indicative of high autotrophic 
Table 2. Contributions of various acid-base systems to the acidbase buffering capacity $\beta$ in August at 1 and $32 \mathrm{~m}$ depth.

\begin{tabular}{lcc}
\hline Acid-base system & $\begin{array}{c}\text { Oxic surface water } \\
\left(\mathrm{pH}_{\mathrm{T}}=8.28\right)\end{array}$ & $\begin{array}{c}\text { Anoxic bottom water } \\
\left(\mathrm{pH}_{\mathrm{T}}=7.52\right)\end{array}$ \\
\hline Carbonate & $72.99 \%$ & $81.14 \%$ \\
Borate & $24.41 \%$ & $17.44 \%$ \\
Water (auto-dissociation) & $2.42 \%$ & $0.72 \%$ \\
Phosphate & $0.09 \%$ & $0.30 \%$ \\
Silicate & $0.08 \%$ & $0.29 \%$ \\
Ammonium & $0.00 \%$ & $0.08 \%$ \\
Other & $0.00 \%$ & $0.03 \%$ \\
\hline
\end{tabular}

activity. Water-column ventilation disrupted the surface-tobottom $p \mathrm{CO}_{2}$ difference from September onwards. Mean water-column $p \mathrm{CO}_{2}$ decreased from 584 to $490 \mathrm{ppmv}$ between September and December, although $p \mathrm{CO}_{2}$ values were slightly higher in November, especially in the bottom water (601 ppmv on average). Note that, in contrast to January, the average water-column $p \mathrm{CO}_{2}$ in December was much higher than $p \mathrm{CO}_{2, \text { atm }}(398 \mathrm{ppmv})$. Similar to $\mathrm{pH}_{\mathrm{T}}$, $p \mathrm{CO}_{2}$ variation over the year was higher in the bottom water (1099 ppmv) than in the surface water (375 ppmv).

We investigated the correlation between the different carbonate system parameters and $\mathrm{O}_{2}$ by calculating coefficients of determination and testing their significance using the package Stats in R. In line with our visual observations, we found a strong correlation between $\mathrm{pH}_{\mathrm{T}}$ and $p \mathrm{CO}_{2}\left(r^{2}=\right.$ $0.89, P<0.001)$ and weak to moderate correlations between $\mathrm{pH}_{\mathrm{T}}$ and $\mathrm{O}_{2}\left(r^{2}=0.68, P<0.001\right), p \mathrm{CO}_{2}$ and $\mathrm{O}_{2}\left(r^{2}=\right.$ $0.70, P<0.001)$, and DIC and TA $\left(r^{2}=0.56, P<0.001\right)$. DIC does not appear to be correlated with $\mathrm{pH}_{\mathrm{T}}\left(r^{2}=0.18\right.$, $P<0.001), p \mathrm{CO}_{2}\left(r^{2}=0.17, P<0.001\right)$ or $\mathrm{O}_{2}\left(r^{2}=0.21\right.$, $P<0.001)$. Finally, as expected, TA could not statistically significantly be correlated to $\mathrm{pH}_{\mathrm{T}}\left(r^{2}=0.01, P=0.278\right)$, $p \mathrm{CO}_{2}\left(r^{2}=0.01, P=0.384\right)$ or $\mathrm{O}_{2}\left(r^{2}=0.04, P=0.066\right)$.

\subsubsection{Acid-base buffering capacity}

The acid-base buffering capacity generally showed a similar spatio-temporal pattern to $\mathrm{pH}_{\mathrm{T}}$ and the inverse of the $p \mathrm{CO}_{2}$ pattern (Fig. 4e). In January, $\beta$ had an average value of 22967 and hardly varied with depth. From February to April, the buffering capacity increased throughout the water column, with a faster increase in the surface compared to the bottom water and a maximum of 82557 in the surface water in April. In May and June, the acid-base buffering capacity showed an overall decline. In contrast to $\mathrm{pH}_{\mathrm{T}}$, the onset of stratification did not lead to a direct amplification of the difference between surface and bottom water $\beta$. July was characterised by a sharp increase in surface-water $\beta$, coinciding with the decrease in DIC, and a decrease in bottom-water $\beta$, a trend that was intensified in August. During this period of strongest hypoxia, surface-water $\beta$ (71 454) was an order of magnitude higher than bottom-water $\beta$ (6802). Between September and
December, i.e. after bottom-water ventilation, the buffering capacity did not show any substantial variations with depth. Over the course of the year, surface-water $\beta$ varied by a factor of 2 more than bottom-water $\beta$.

To assess the effect of temperature on the acid-base buffering capacity, we calculated $\beta$ for each month and depth using the annual average temperature at Den Osse, which was $10.8^{\circ} \mathrm{C}$ for 2012 . From this, we calculated the anomaly in $\beta$ as the difference between the actual and isothermally calculated values for $\beta$. This analysis shows that the $\beta$ anomaly is negatively correlated with the $T$ anomaly, i.e. an increase in temperature leads to a decrease in the acid-base buffering capacity. However, $\beta$ changed by at most $\sim 30000$ as a result of the range of temperatures the Den Osse Basin experienced in 2012, while the actual seasonal variation in the acid-base buffering capacity exceeds 60000 . Temperature thus only partly explains the variation in $\beta$ over the year. To further elucidate what controls the acid-base buffering capacity, we calculated the contribution of various acid-base systems to $\beta$ for the surface and bottom water in August (Table 2). This calculation shows that in the oxic surface water, where $\beta$ is high, the relative contribution of the borate system to the total buffering capacity was higher than in the anoxic, poorly buffered bottom water ( 24 and $17 \%$, respectively), while the reverse holds for the carbonate system (73 vs. $81 \%$ ). Acidbase systems other than the carbonate and borate system contributed most to the buffering capacity in the anoxic bottom water, due to the accumulation of $\mathrm{NH}_{4}^{+}, \mathrm{PO}_{4}^{3-}$ and $\mathrm{Si}(\mathrm{OH})_{4}$. However, their total contribution never exceeded $1 \%$.

\subsection{Rate calculations}

\subsubsection{Gross primary production and community respiration}

Chl $a$, which was used as an indicator for algal biomass, showed three periods of elevated concentrations (Fig. 4f). In March, surface-water [Chl $a$ ] showed a slight increase up to $5.2 \mu \mathrm{g} \mathrm{L}{ }^{-1}$. In May, elevated [Chl $a$ ] could be found between 6 and $15 \mathrm{~m}$, with a subsurface maximum of $19.0 \mu \mathrm{g} \mathrm{L}^{-1}$ at $10 \mathrm{~m}$ depth. Finally, the most prominent peak in $[\mathrm{Chl} a]$ $\left(27.3 \mu \mathrm{g} \mathrm{L}^{-1}\right)$ was found in the surface water in July. Together with elevated $\left[\mathrm{O}_{2}\right]$ and $\mathrm{pH}_{\mathrm{T}}$ and a drawdown of DIC and $p \mathrm{CO}_{2}$, this indicated the presence of a major phytoplankton bloom. Microscopic observations of phytoplankton samples from this bloom showed that it consisted mainly of the dinoflagellate Prorocentrum micans.

Measured volumetric rates of GPP ranged from 0.0 to $150.7 \mathrm{mmol} \mathrm{C} \mathrm{m}^{-3} \mathrm{~d}^{-1}$ (Fig. 5a), while volumetric $\mathrm{CR}$ ranged from $0.0-31.5 \mathrm{mmol} \mathrm{C} \mathrm{m}^{-3} \mathrm{~d}^{-1}$ (Fig. 5b). To a large extent, their spatio-temporal patterns confirm the trends in [Chl $a$ ]. GPP showed a distinct seasonal pattern, with one major peak in July $2012\left(151 \mathrm{mmol} \mathrm{C} \mathrm{m}^{-3} \mathrm{~d}^{-1}\right.$ at $1 \mathrm{~m}$ depth) coinciding with high surface water $[\mathrm{Chl} a]$ and CR $(31 \mathrm{mmol}$ $\mathrm{C} \mathrm{m}^{-3} \mathrm{~d}^{-1}$ ). Elevated $\mathrm{CR}$ in August between 6 and $10 \mathrm{~m}$ 


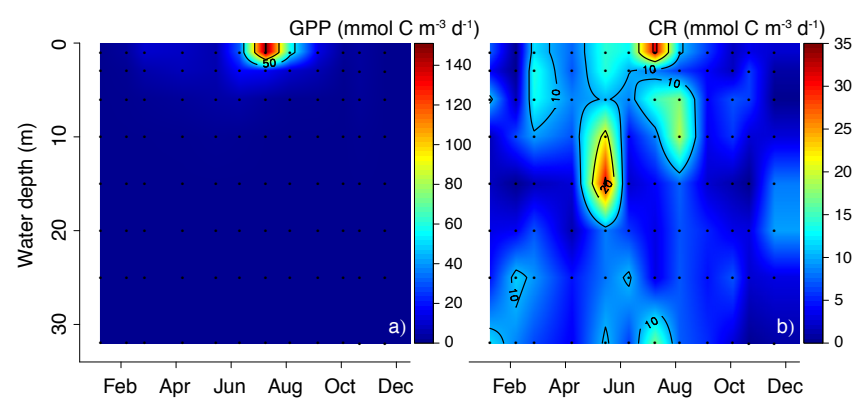

Figure 5. Volumetric rates of (a) GPP $\left(\mathrm{mmol} \mathrm{C} \mathrm{m}^{-3} \mathrm{~d}^{-1}\right)$ and (b) $\mathrm{CR}\left(\mathrm{mmol} \mathrm{C} \mathrm{m}{ }^{-3} \mathrm{~d}^{-1}\right)$ at Den Osse in 2012. Black dots indicate sampling intervals. Rates were calculated as described in Sect. 2.4.

depth (19 mmol $\left.\mathrm{C} \mathrm{m}^{-3} \mathrm{~d}^{-1}\right)$ may reflect degrading algal material from this bloom. Although surface water [Chl $a$ ] showed a slight increase in March, this was not reflected in the GPP during this month (maximum $9.4 \mathrm{mmol} \mathrm{C} \mathrm{m}^{-3} \mathrm{~d}^{-1}$ ). The peak in $[\mathrm{Chl} a]$ in May correlated with a major peak in CR (maximum $31 \mathrm{mmol} \mathrm{C} \mathrm{m}^{-3} \mathrm{~d}^{-1}$ ) but not in GPP. Since this Chl $a$ subsurface maximum was close to the LPD of $10.6 \mathrm{~m}$, this indicates that this algal biomass could not substantially contribute to GPP, as confirmed by the rate measurements. Hence, it presumably represented sinking algal biomass that was being degraded. The fact that the Chl $a$ peak at ca. $10 \mathrm{~m}$ depth in May was not preceded by a surface water Chl $a$ peak of equal magnitude could mean that part of the algal biomass may not have formed in situ, but was imported with North Sea water. As an alternative explanation, there was a relatively long period between sampling in March and April (42 days) and between sampling in April and May (37 days). This means that in either of those periods an algal bloom could have formed and led to the increase in CR in May. Between March and May, $\left[\mathrm{NH}_{4}^{+}\right]$declined from 0.76 to $0.00 \mu \mathrm{mol} \mathrm{kg} \mathrm{kg}^{-1}$ and $\left[\mathrm{NO}_{3}^{-}\right.$] from 20.6 to $0.08 \mu \mathrm{mol} \mathrm{kg}^{-1}$ (see online supplementary information), supporting the idea of a bloom between sampling dates.

To assess the metabolic balance in the surface water, we averaged the volumetric GPP and CR in the photic zone. This analysis reveals that in summer, from June to September, volumetric GPP was higher than CR above the light penetration depth. Before and after this period, average photic zone CR was higher than GPP. This is another indication that a significant part of the organic carbon respired within the surface water layer was not produced in situ, emphasising the potential importance of lateral input of detrital matter at the field site. Yearly integrated GPP averaged over the photic zone was estimated to be $2494 \mathrm{mmol} \mathrm{C} \mathrm{m}^{-3} \mathrm{yr}^{-1}$, which amounts to an average of $6.8 \mathrm{mmol} \mathrm{C} \mathrm{m}^{-3} \mathrm{~d}^{-1}$. Annual depth-weighted photic zone $\mathrm{CR}$ was slightly higher than GPP, i.e. $2852 \mathrm{mmol} \mathrm{C} \mathrm{m}^{-3} \mathrm{yr}^{-1}$ or $7.8 \mathrm{mmol} \mathrm{C} \mathrm{m}^{-3} \mathrm{~d}^{-1}$. Depth-weighted volumetric CR below the photic zone, the annual rate of which was approximated at $2232 \mathrm{mmol} \mathrm{C} \mathrm{m}^{-3} \mathrm{yr}^{-1}$ or $6.1 \mathrm{mmol} \mathrm{C} \mathrm{m}^{-3} \mathrm{~d}^{-1}$,
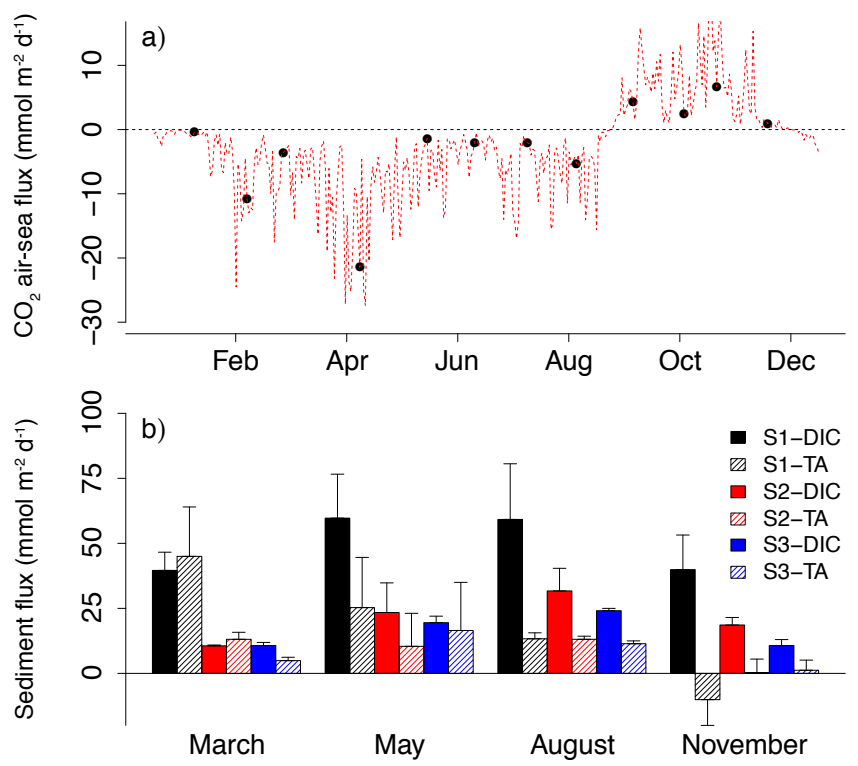

Figure 6. (a) $\mathrm{CO}_{2}$ air-sea flux $\left(\mathrm{mmol} \mathrm{C} \mathrm{m}{ }^{-2} \mathrm{~d}^{-1}\right)$ and (b) total sediment DIC and TA fluxes $\left(\mathrm{mmol} \mathrm{m}^{-2} \mathrm{~d}^{-1}\right)$ at three different depths $(\mathrm{S} 1=34, \mathrm{~S} 2=23$, and $\mathrm{S} 3=17 \mathrm{~m})$ in the Den Osse basin. $\mathrm{CO}_{2}$ air sea flux was interpolated using linear interpolation of the $\mathrm{CO}_{2}$ seaair gradient and daily averaged wind speed data measured at Wilhelminadorp $\left(51.527^{\circ} \mathrm{N}, 3.884^{\circ} \mathrm{E}\right)$. Sediment fluxes were obtained from core incubations executed in triplicate (see Sect. 2.5).

was lower than average photic zone CR except for February and December.

\subsection{2 $\mathrm{CO}_{2}$ air-sea exchange}

For most of 2012, the surface water $(1 \mathrm{~m})$ of the Den Osse basin was undersaturated with respect to $p \mathrm{CO}_{2}$,atm, which led to $\mathrm{CO}_{2}$ uptake from the atmosphere (Fig. 6a). In January, surface-water $p \mathrm{CO}_{2}$ was very close to $p \mathrm{CO}_{2}$,atm, resulting in a very small influx. From February to April, surface-water $p \mathrm{CO}_{2}$ steadily declined to a value of $199 \mathrm{ppmv}$ in April. This brought about an increasingly larger gradient and a $\mathrm{CO}_{2}$ uptake that was highest in April $\left(21.4 \mathrm{mmol} \mathrm{C} \mathrm{m}^{-2} \mathrm{~d}^{-1}\right)$. Surface-water $p \mathrm{CO}_{2}$ increased in late spring until a value of $350 \mathrm{ppmv}$ in June, after which it declined to $202 \mathrm{ppmv}$ in August. Water-column ventilation from September onwards brought $\mathrm{CO}_{2}$-rich bottom water to the surface, leading to a surface-water $p \mathrm{CO}_{2}$ value exceeding that of the atmosphere and inducing strong outgassing of $\mathrm{CO}_{2}$ towards the atmosphere. Outgassing continued until the end of 2012, albeit with a smaller magnitude due to a decrease in surface water $p \mathrm{CO}_{2}$ to 411 ppmv in December.

Although the direction of the $\mathrm{CO}_{2}$ air-sea flux is solely determined by the saturation state of surface water with respect to $p \mathrm{CO}_{2 \text {,atm }}$, its magnitude is also influenced by the gas transfer velocity $k$, which is parameterised as a function of wind speed. Daily-averaged wind speed over 2012 varied between 1.5 and $14.5 \mathrm{~m} \mathrm{~s}^{-1}$, with an average of $4.6 \mathrm{~m} \mathrm{~s}^{-1}$. 
With the exception of January, February, April and December, our samples were taken on days with wind speeds below average (see online supplementary information). We interpolated the $\mathrm{CO}_{2}$ air-sea flux as described in Sect. 2.6 (red dotted line in Fig. 6a). When integrated over the year, this leads to a value of $-0.98 \mathrm{~mol} \mathrm{C} \mathrm{m}^{-2} \mathrm{yr}^{-1}$, or an average flux of $-2.66 \mathrm{mmol} \mathrm{C} \mathrm{m}^{-2} \mathrm{~d}^{-1}$, indicating that the Den Osse basin was a weak sink for $\mathrm{CO}_{2}$.

\subsubsection{Sediment fluxes}

In all months, sediment DIC fluxes were highest at S1 (Fig. 6b). Since $\mathrm{S} 1$ is located at the deepest point of the Den Osse basin, it receives the highest input of organic matter through both sinking and lateral transport. S2 and S3 showed similar DIC fluxes throughout the year, with the exception of November, when the flux at S2 $\left(18.6 \pm 2.9 \mathrm{mmol} \mathrm{m}^{-2} \mathrm{~d}^{-1}\right)$ exceeded that of $\mathrm{S} 3\left(10.7 \pm 2.3 \mathrm{mmol} \mathrm{m}^{-2} \mathrm{~d}^{-1}\right)$. In August, DIC fluxes at S2 and S3 were substantially higher than in the other months. During this month, the amount of organic matter sinking through the water column may have been high as a result of a peak in primary production in the preceding month.

The sediment TA fluxes generally showed much more site-specific variability, making it difficult to identify any spatial or temporal patterns. TA fluxes in March showed a clear spatial variability, with the highest flux at $\mathrm{S} 1 \quad\left(45.0 \pm 19.0 \mathrm{mmol} \mathrm{m}^{-2} \mathrm{~d}^{-1}\right)$, followed by S2 $\left(13.1 \pm 2.7 \mathrm{mmol} \mathrm{m}^{-2} \mathrm{~d}^{-1}\right)$ and $\mathrm{S} 3$ $\left(4.9 \pm 1.3 \mathrm{mmol} \mathrm{m}^{-2} \mathrm{~d}^{-1}\right)$. May and August did not display any difference between stations or months, with fluxes varying from $10.4 \pm 12.7$ to $25.3 \pm 19.3 \mathrm{mmol} \mathrm{m}^{-2} \mathrm{~d}^{-1}$. In November, TA fluxes at S2 $\left(0.3 \pm 5.2 \mathrm{mmol} \mathrm{m}^{-2} \mathrm{~d}^{-1}\right)$ and S3 $\left(1.2 \pm 3.9 \mathrm{mmol} \mathrm{m}^{-2} \mathrm{~d}^{-1}\right)$ were similar and very small, while $\mathrm{S} 1$ showed an uptake rather than a release of TA $\left(-10.1 \pm 9.9 \mathrm{mmol} \mathrm{m}^{-2} \mathrm{~d}^{-1}\right)$, likely because of reoxidation processes that consume TA. Beggiatoa spp. were abundant in these sediments in November (Seitaj et al., 2015a) and their activity may generate a decrease in surface-sediment TA (Sayama et al., 2005).

For most of the year, the ratio of sediment DIC to TA flux was higher than 1 , meaning that more DIC than TA was released from the sediments. Only in March at S1 and S2, the efflux of TA was higher than that of DIC. Because of the sedimentary uptake of TA at $\mathrm{S} 1$ in November, the corresponding DIC : TA was negative.

\section{Discussion}

\subsection{Community metabolism}

In 2012, Lake Grevelingen experienced a major phytoplankton bloom in summer (July), a minor bloom with completely different dynamics in early spring (March), and a potential third bloom in late spring (April). The minor March bloom is reflected in a slightly elevated surface water $[\mathrm{Chl} a]$ and $\mathrm{pH}_{\mathrm{T}}$, no obvious peak in GPP, but a small peak in CR. The major peak in CR in May, accompanied by a Chl $a$ peak at $10 \mathrm{~m}$ depth, could result from the early spring bloom, as we might not have captured its full extent, or the potential late spring bloom (see Sect. 3.3.1). However, it most likely represents laterally transported degrading Phaeocystis globosa, the haptophyte that makes up the spring bloom in the southern part of the North Sea (Cadée and Hegeman, 1991). Highest $P$. globosa cell counts have been found between mid-April and mid-May, corresponding to the timing of the CR peak, at the mouth of the Eastern Scheldt $\left(51.602^{\circ} \mathrm{N}, 3.721^{\circ} \mathrm{E}\right)$ between 1990 and 2010 (Wetsteyn, 2011), and off the Belgian coast between 1989 and 1999 (Lancelot et al., 2007). Moreover, the years with high $P$. globosa cell counts at the mouth of the Eastern Scheldt coincided with a large area of low-oxygen water in the entire Lake Grevelingen (Peperzak and Poelman, 2008; Wetsteyn, 2011), highlighting the connection between P. globosa blooms and $\mathrm{O}_{2}$ consumption in the lake. The high $\mathrm{CR}$ in May combined with the onset of stratification led to a rapid decline in bottom water $\left[\mathrm{O}_{2}\right]$. The major dinoflagellate bloom in July was short but very intense in terms of GPP and $[\mathrm{Chl} a]$ and appeared to contribute to the sharp increase in hypoxic water volume between June and August. Sinking P. micans from this bloom was degraded, which is reflected in higher CR in July and August compared to June, and the products of this degradation were trapped in the water below the pycnocline, as is indicated by elevated DIC levels. However, the higher CR in July and August and subsequent decline in $\left[\mathrm{O}_{2}\right]$ may also result from higher water temperatures (Fig. 3a), resulting in faster degradation of allochthonous organic matter. The drawdown of bottom-water $\mathrm{O}_{2}$ is, however, not due to $\mathrm{CR}$ alone. The fact that $\left[\mathrm{O}_{2}\right]$ declines with depth at all months indicates that sediment oxygen uptake may be an important process affecting water-column $\left[\mathrm{O}_{2}\right]$. Indeed, substantial sediment $\mathrm{O}_{2}$ uptake was found to take place yearround with rates up to $61 \mathrm{mmol} \mathrm{m}^{-2} \mathrm{~d}^{-1}$ at $\mathrm{S} 1$ (Seitaj et al., 2015b).

Our depth-weighted, annually averaged CR of $7.8 \mathrm{mmol}$ $\mathrm{C} \mathrm{m}^{-3} \mathrm{~d}^{-1}$ in the photic zone and $6.1 \mathrm{mmol} \mathrm{C} \mathrm{m}^{-3} \mathrm{~d}^{-1}$ below the LPD are similar to estimates from the nearby located Western Scheldt, where annually averaged CR ranged from 4.7-19.1 mmol $\mathrm{C} \mathrm{m}^{-3} \mathrm{~d}^{-1}$, with a mean value of $6.6 \mathrm{mmol} \mathrm{C} \mathrm{m}^{-3} \mathrm{~d}^{-1}$ (Gazeau et al., 2005b). In the mesohaline part of the seasonally hypoxic Chesapeake Bay, summertime surface-water CR was found to vary between 9.8$53.0 \mathrm{mmol} \mathrm{C} \mathrm{m}^{-3} \mathrm{~d}^{-1}$, while bottom-water CR varied between 0-45.6 $\mathrm{mmol} \mathrm{C} \mathrm{m}^{-3} \mathrm{~d}^{-1}$ (Lee et al., 2015). Thus, our measurements of $\mathrm{CR}$ are well within the range of published values, both for the Dutch coastal zone and for other seasonally hypoxic basins.

Recent modelling studies and previous measurement campaigns have presented lake-wide estimates of GPP ranging from $100 \mathrm{~g} \mathrm{C} \mathrm{m}^{-2} \mathrm{yr}^{-1}$ (Nienhuis and Huis in 't Veld, 1984) to $572 \mathrm{~g} \mathrm{C} \mathrm{m}^{-2} \mathrm{yr}^{-1}$ (Meijers and Groot, 2007). When 
integrating annual volumetric GPP over the depth of the photic zone, we arrive at an estimate of GPP for the Den Osse basin of $225 \mathrm{~g} \mathrm{C} \mathrm{m}^{-2} \mathrm{yr}^{-1}$ in 2012. Given the different methods used and time periods considered, our estimate of GPP is consistent with these previous studies. In comparison with other coastal systems in the Netherlands, GPP in the Den Osse basin is somewhat lower than that in the adjacent Eastern Scheldt $\left(200-550 \mathrm{~g} \mathrm{C} \mathrm{m}^{-2} \mathrm{yr}^{-1}\right.$; Wetsteyn and Kromkamp, 1994) and of similar magnitude to that in the western Wadden Sea between 1988 and 2003 (185 $\pm 13 \mathrm{~g} \mathrm{C} \mathrm{m}^{-2} \mathrm{yr}^{-1}$; Philippart et al., 2007) and in the Western Scheldt in 2003 ( $150 \mathrm{~g} \mathrm{C} \mathrm{m}^{-2} \mathrm{yr}^{-1}$; Gazeau et al., 2005b).

\subsection{Proton cycling due to GPP and CR}

The fluctuations in $\mathrm{pH}_{\mathrm{T}}$ as shown in Fig. 4a result from the balance between rates and stoichiometry of protonproducing and -consuming processes, mediated by the acidbase buffering capacity of the water. Taking into account that variations in the stoichiometric coefficient for the proton are relatively minor (Table 1 ) compared to changes in process rates (Figs. 5 and 6) and acid-base buffering capacity (Fig. 4e), we will focus our discussion mainly on the latter two.

Any biogeochemical process will either consume or produce protons based on its stoichiometry, as the reaction always proceeds in the forward direction. The signs of $v_{\mathrm{H}^{+}}^{x}$ in Table 1 indicate whether a process produces (positive) or consumes (negative) protons. Thus, CR and nitrification increase $\left[\mathrm{H}^{+}\right]$, while GPP leads to an increase in $\mathrm{pH}$. For transport processes, the direction of the flux determines whether protons are produced or consumed. For example, $\mathrm{CO}_{2}$ uptake from the atmosphere leads to an increase in $\left[\mathrm{H}^{+}\right]$, while outgassing of $\mathrm{CO}_{2}$ to the atmosphere consumes protons. For vertical transport and sediment-water exchange, the direction of the net change in $\left[\mathrm{H}^{+}\right]$depends on the ratio of TA to DIC flux entering the water mass. When the flux of TA exceeds that of DIC, protons are consumed. On the contrary, when DIC fluxes are higher than TA fluxes, the net effect is an increase in $\left[\mathrm{H}^{+}\right]$. Considering the magnitude of the seasonal variability in the various process rates measured at Den Osse, they must significantly impact $\mathrm{H}^{+}$dynamics.

Aside from this, the spatio-temporal variations in buffering capacity (Fig. 4e) also exert a major control on the proton cycling in this basin. Taking the month of August as an example, $\beta$ decreases by one order of magnitude when going from surface to bottom water. When the rate of a certain process does not change with depth, the number of protons produced or consumed by this process per $\mathrm{kg}$ of water is 1 order of magnitude higher in the bottom water than in the surface water (see Eq. 7). This indicates that, in August, the bottom water is much more prone to changes in $\mathrm{pH}$ than the surface water. In line with previous studies focusing on the $\mathrm{CO}_{2}$ buffering capacity (e.g. Thomas et al., 2007; Shadwick et al., 2013), temperature was found to exert an important control on the seasonal variability of the acid-base buffering capacity in the Den Osse Basin. The fact that the contribution of acid-base systems other than the carbonate and borate system to $\beta$ is highest in the anoxic bottom water is in line with previous work (e.g. Ben-Yaakov, 1973; Soetaert et al., 2007). However, their small contribution in the Den Osse basin contrasts with results from the Eastern Gotland basin in the Baltic Sea. Here, generation of TA during remineralisation under anoxic conditions by denitrification, sulphate reduction and the release of $\mathrm{NH}_{4}^{+}$and $\mathrm{PO}_{4}^{3-}$, and the resultant increase in buffering capacity were found to contribute significantly to the observed changes in $\mathrm{pH}$ (Edman and Omstedt, 2013).

To understand how variations in both process rates and acid-base buffering capacity control proton cycling in the Den Osse basin, we used Eq. (7) to calculate the change in $\left[\mathrm{H}^{+}\right]\left(\mu \mathrm{mol} \mathrm{kg} \mathrm{kg}^{-1} \mathrm{~d}^{-1}\right)$ due to GPP at $1 \mathrm{~m}$ depth and CR at 1 and $25 \mathrm{~m}$ depth. This analysis reveals that it is the interplay between GPP (Fig. 7d) and $\beta$ (Fig. 7b) that drives temporal variations in $\frac{\mathrm{d}\left[\mathrm{H}^{+}\right]_{G P P}}{\mathrm{~d} t}$ (Fig. 7e). The seasonal pattern of $\frac{\mathrm{d}\left[\mathrm{H}^{+}\right]_{\mathrm{GPP}}}{\mathrm{d} t}$ resembles that of GPP, but its magnitude is significantly modulated by $\beta$, especially in late summer. For example, GPP in August was 4.6 times higher than that of September (57.9 and $12.6 \mu \mathrm{mol} \mathrm{kg}^{-1} \mathrm{~d}^{-1}$, respectively), but $\frac{\mathrm{d}\left[\mathrm{H}^{+}\right]_{\mathrm{GPP}}}{\mathrm{d} t}$ in August was only 1.8 times higher. This difference cannot be explained by $v_{\mathrm{H}^{+}}^{\text {GPP }}$ (Fig. 7c), which had a higher magnitude in August $(-1.31)$ in comparison with September $(-0.92)$, due to a switch from $\mathrm{NO}_{3}^{-}$to $\mathrm{NH}_{4}^{+}$uptake (Sect. 2.4). Thus, the relatively high proton consumption in September was driven by the lower surface-water buffering capacity, which is a factor of 3.7 smaller in September compared to August (71 454 vs. 19474). When comparing $\frac{\mathrm{d}\left[\mathrm{H}^{+}\right]_{\mathrm{GPP}}}{\mathrm{d} t}$ and $\frac{\mathrm{d}\left[\mathrm{H}^{+}\right]_{\mathrm{CR}}}{\mathrm{d} t}$ in the surface layer (Fig. 7e), we see that when GPP was higher than $\mathrm{CR}$, the decrease in $\left[\mathrm{H}^{+}\right]$ due to GPP was also higher than the increase in $\left[\mathrm{H}^{+}\right]$due to $\mathrm{CR}$. This can simply be explained by the fact that $\beta$ was the same for both processes (Fig. 7b), and the effect of $v_{\mathrm{H}^{+}}^{\mathrm{GPP}}$ was only minor (Fig. 7c), so that the difference between $\frac{\mathrm{d}\left[\mathrm{H}^{+}\right]_{\mathrm{GPP}}}{\mathrm{d} t}$ and $\frac{\mathrm{d}\left[\mathrm{H}^{+}\right]_{\mathrm{CR}}}{\mathrm{d} t}$ can directly be linked to the difference between GPP and CR (Fig. 7d). Some clear differences between the patterns of $\frac{\mathrm{d}\left[\mathrm{H}^{+}\right]_{C R}}{\mathrm{~d} t}$ at 1 and $25 \mathrm{~m}$ depth can be identified (Fig. 7e). With the exception of February, October and December, volumetric CR was higher at $1 \mathrm{~m}$ depth than at $25 \mathrm{~m}$ depth (Fig. 7d). Thus, the higher $\frac{\mathrm{d}\left[\mathrm{H}^{+}\right]_{\mathrm{CR}}}{\mathrm{d} t}$ in June and August at $25 \mathrm{~m}$ compared to $1 \mathrm{~m}$ depth was solely driven by the lower acid-base buffering capacity of the bottom water (Fig. 7b). In July, on the contrary, CR at $1 \mathrm{~m}$ depth was so much higher than at $25 \mathrm{~m}$ depth ( 30.8 vs. $\left.2.9 \mu \mathrm{mol} \mathrm{kg}{ }^{-1} \mathrm{~d}^{-1}\right)$ that this compensated for the lower buffering capacity at depth $(65373$ vs. 10025$)$ and led to a higher surface-water $\frac{\mathrm{d}\left[\mathrm{H}^{+}\right]_{\mathrm{CR}}}{\mathrm{d} t}$. Again, this highlights that the magnitudes of both $\mathrm{CR}$ and $\beta$ play a role in determining the actual change in $\mathrm{pH}$. 


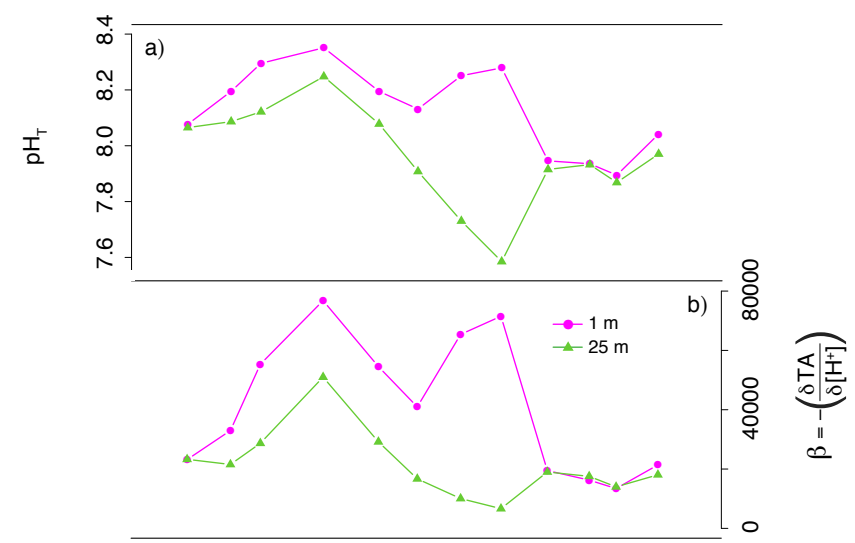

\subsection{Proton budget for the Den Osse basin}

To further elucidate the driving mechanisms of $\mathrm{pH}$ fluctuations, we calculated a full proton budget for each of the four seasons in 2012. One should realise that these proton budgets are among the first of their kind based on measured data and contain many uncertainties. Figure 8 shows these budgets for 1 and $25 \mathrm{~m}$ depth; the budgets for the other depths can be found in the online supplementary information. This calculation illustrates that of all the measured processes, GPP and CR generally had the highest contribution to proton cycling intensity in 2012. CR always dominated the total proton production between 4.5 and $17.5 \mathrm{~m}$ and was usually a major contributing process above and below this interval. In the surface water GPP accounted for 34.8-99.2\% of $\mathrm{H}^{+}$consumption, but deeper in the photic zone GPP still accounted for a significant part of the proton removal $(2.7-30.3 \%$ between 4.5 and $8 \mathrm{~m}$ depth). $\mathrm{CO}_{2}$ air-sea exchange usually played a minor role in the surface-water proton cycling, apart from November when outgassing of $\mathrm{CO}_{2}$ was high, and $56.6 \%$ of the total proton consumption in the surface water was due to this process. In March, $\mathrm{CO}_{2}$ air-sea exchange contributed $14.2 \%$ to the budget, while in May and August, its influence was less than $6 \%$. Nitrification accounted for $0.00-34.4 \%$ of the total proton production and was mostly a significant proton cycling process in November and in May below $17.5 \mathrm{~m}$ depth. The change in temperature from one day to the next contributed $0.2-30.7 \%$ to the proton cycling intensity and was generally a more important factor in the proton budget in March and November than in May and August. The effect of vertical mixing was even less pronounced, as it accounted for only $0.04-12.7 \%$ of the proton cycling intensity throughout the water column.

With the exception of March, the net result of the TA and DIC fluxes from the sediment was the dominant contributor to the total $\mathrm{H}^{+}$production in the bottom layer (62.3-99.4\%). Higher up in the basin, its contribution ranged from 2.6 to $49.2 \%$. In March, the net result of the sediment flux at S1 was a contribution of $24.0 \%$ to the total proton consumption, while at S2 and S3 its effect on the budget was less than $10 \%$. During all months and at all depths, the absolute value of $\frac{\mathrm{d}\left[\mathrm{H}^{+}\right]_{\mathrm{CR}}}{\mathrm{d} t}$ was larger than that of $\frac{\Delta\left[\mathrm{H}^{+}\right]_{\text {obs }}}{\Delta t}$. This was also usually the case for $\frac{\mathrm{d}\left[\mathrm{H}^{+}\right]_{\mathrm{GPP}}}{\mathrm{d} t}, \frac{\mathrm{d}\left[\mathrm{H}^{+} l_{\text {exch }}\right.}{\mathrm{d} t}$ and $\frac{\mathrm{d}\left[\mathrm{H}^{+}\right]_{\text {sed }}}{\mathrm{d} t}$, and in March and November for $\frac{\mathrm{d}\left[\mathrm{H}^{+}\right]_{\text {nitr }}}{\mathrm{d} t}$ and $\frac{\mathrm{d}\left[\mathrm{H}^{+}\right]_{\text {temp }}}{\mathrm{d} t}$, at the depths where these processes took place. Thus, as was the case for another coastal system (Hofmann et al., 2009), the final change in $\left[\mathrm{H}^{+}\right]$resulting from all proton-producing and -consuming processes was much smaller than the change in $\left[\mathrm{H}^{+}\right]$induced by each of the separate processes.

The sum of $\frac{\mathrm{d}\left[\mathrm{H}^{+}\right]_{x}}{\mathrm{~d} t}$ of all measured processes $\left(\frac{\mathrm{d}\left[\mathrm{H}^{+}\right]_{\text {tot }}}{\mathrm{d} t}\right.$; Eq. 8) was 1-2 orders of magnitude higher than $\frac{\Delta\left[\mathrm{H}^{+}\right]_{\text {obs }}}{\Delta t}$. As a result, the budget closure term dominated the proton cycling intensity, with the exception of the surface water in 
$\left[\mathrm{H}^{+}\right]$change $\left(\mu \mathrm{mol} \mathrm{kg}^{-1} \mathrm{~d}^{-1}\right)$
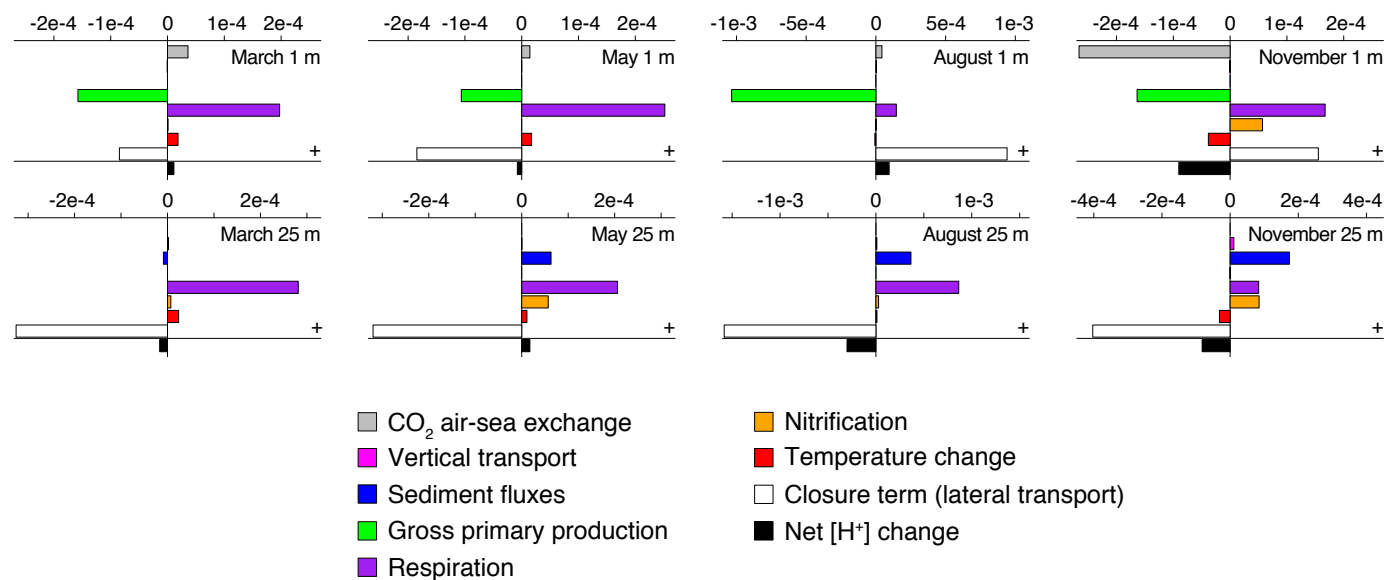

Figure 8. Proton budget for the Den Osse basin at 1 and $25 \mathrm{~m}$ depth for the months of March, May, August and November. The closure term is calculated as the difference between the calculated and measured net change in $\left[\mathrm{H}^{+}\right]$.

March and November. Its contribution ranged from 34.8 to $100 \%$ of the total $\mathrm{H}^{+}$production or consumption, the latter depending on the sign of the budget closure term. The dominance of the closure term highlights the uncertainties underlying the current proton cycling budget. These uncertainties arise from spatial and temporal variability, measurement error and incomplete coverage of all processes affecting proton cycling. Taking the sediment fluxes (Fig. 6b) as an example, we see that the standard deviation of both the TA and DIC fluxes, which mostly results from small-scale spatial variability, ranges up to $\sim 100 \%$ of the measured flux. This imposes a large uncertainty on the corresponding proton flux, which may severely impact the bottom-water proton budget. Similarly, by using an empirical nitrification rate expression based on $\left[\mathrm{NH}_{4}^{+}\right]$and $\left[\mathrm{O}_{2}\right]$, we ignore temporal variability caused by, for example, changes in the microbial community. As the nitrification rate, like the other process rates, linearly correlates with the amount of protons produced, changes therein may especially impact the proton budget in November.

Since $\frac{\mathrm{d}\left[\mathrm{H}^{+}\right]_{\text {tot }}}{\mathrm{d} t}$ was mostly positive, the processes making up the closure term generally had to decrease $\left[\mathrm{H}^{+}\right]$, i.e. remove protons from the basin. Taking account of both its order of magnitude and direction of change, we calculated that lateral transport may have accounted for the budget closure term. The average inflow in Lake Grevelingen through the seaward sluice in 2012 was $221 \mathrm{~m}^{3} \mathrm{~s}^{-1}$ and took place for $9.9 \mathrm{~h}$ per day (calculated based on sluice water levels measured at 10 min intervals; P. Lievense, personal communication, 2013). Meijers and Groot (2007) showed that 30.2\% of the water entering Lake Grevelingen through the sluice remains in the lake for a longer period of time and is not directly transported back during the consecutive period of outflow. This means that, per day, $24 \times 10^{5} \mathrm{~m}^{3}$ of North Sea water enters Lake Grevelingen. Assuming that all of this water eventually reaches the Den Osse basin and taking account of the total volume of this basin $\left(655 \times 10^{5} \mathrm{~m}^{3}\right)$, this means that the inflow of the seaward sluice can fully replenish the Den Osse basin in 30 days. The average density of the water in the basin in 2012 was $1023.7 \mathrm{~kg} \mathrm{~m}^{-3}$. If we assume that the $\mathrm{pH}$ of the inflowing water was 8.2 , or $\left[\mathrm{H}^{+}\right]$was $6.31 \times 10^{-3} \mu \mathrm{mol} \mathrm{kg}{ }^{-1}$, then the proton flux entering the Den Osse basin was $1.55 \times 10^{7} \mu \mathrm{mol} \mathrm{d}^{-1}$. Dividing this by the total volume of the Den Osse basin, which may be a valid assumption if stratification is absent, and correcting for density led to a proton flux of $2.11 \times 10^{-4} \mu \mathrm{mol} \mathrm{kg}^{-1} \mathrm{~d}^{-1}$ into the entire basin. This is in the same order of magnitude as the closure term, which, for example, for the surface water in May was $-1.85 \times 10^{-4} \mu \mathrm{mol} \mathrm{kg} \mathrm{kg}^{-1} \mathrm{~d}^{-1}$. Note, however, that the net proton flux will be smaller as protons are also leaving the basin with outflowing water. Additionally, on both the seaward and landward sides Den Osse is surrounded by shallower waters, which are supposed to have a $\mathrm{pH}$ similar to that of the surface water at Den Osse. Depending on the depths at which water is entering and leaving the Den Osse basin, most likely more protons will be removed from the basin than it will receive from the adjacent water during horizontal water exchange, thus leading to a negative $\frac{\mathrm{d}\left[\mathrm{H}^{+}\right] \text {closure }}{\mathrm{d} t}$. This is in line with the negative sign of the budget closure term for most months.

Over the course of the year, proton turnover time $\left(\tau_{\mathrm{H}^{+}}\right)$ varied substantially. In March (32.8 days) and November (35.9 days), the linearly interpolated and depth-averaged $\tau_{\mathrm{H}^{+}}$ in the basin was much higher than in May (17.7 days) and August (14.4 days). For each month, different driving factors explain these patterns. The proton turnover time is linearly correlated with both ambient $\left[\mathrm{H}^{+}\right]$and $\beta$, and inversely correlated to the process rates. The high average value of $\tau_{\mathrm{H}^{+}}$ in March is mostly explained by a high buffering capacity in combination with low biogeochemical activity. The decrease in May resulted from a significant increase in biogeo- 
chemical and physical process rates, since both the average $\left[\mathrm{H}^{+}\right]$and $\beta$ were higher compared to March. In August, on the contrary, average $\beta$ decreased a factor of 2.6 while average $\left[\mathrm{H}^{+}\right]$increased a factor 2.7 , thereby almost cancelling out each other's effect on $\tau_{\mathrm{H}^{+}}$. The higher turnover time in November, finally, was mostly driven by low process rates in combination with a relatively high average $\left[\mathrm{H}^{+}\right]$. To summarise, the proton turnover time in the Den Osse basin is a complex combination of variability in process rates and buffering capacity, but also depends on the ambient $\mathrm{pH}$.

When the proton turnover time is divided by $\beta$, one calculates the gross proton turnover time, i.e. the turnover time without buffering (Hofmann et al., 2010a). Given that the average $\beta$ in the Den Osse basin is $\sim 30000$ and $\tau_{\mathrm{H}^{+}}$varies between 14.4 and 35.9 days in the 4 months studied, the gross proton turnover time is in the order of minutes. This demonstrates that buffering reactions in active natural systems are extremely important in modulating the net change in $\left[\mathrm{H}^{+}\right]$, and again highlights the fact that $\mathrm{pH}$ dynamics in these settings cannot be studied by measuring process rates alone.

\section{Conclusions}

The Den Osse basin experiences temperature-induced seasonal stratification that, combined with high oxygen consumption, results in the development of hypoxic bottom water with higher DIC and $p \mathrm{CO}_{2}$ and lower $\mathrm{pH}_{\mathrm{T}}$. The strong correlation between $\mathrm{pH}_{\mathrm{T}}$ and $p \mathrm{CO}_{2}$ in 2012 and their moderate correlations with $\mathrm{O}_{2}$ suggest a link between GPP, CR and $\mathrm{pH}_{\mathrm{T}}$, which was further investigated in a detailed proton study. Volumetric GPP showed a major peak in July, while $\mathrm{CR}$ was highest in late spring. Although atmospheric $\mathrm{CO}_{2}$ was taken up for most of the year, the relatively strong outgassing after the termination of stratification resulted in the Den Osse basin being only a weak sink for $\mathrm{CO}_{2}$. Sediment DIC fluxes were highest at the deepest point of the basin and were generally higher than TA fluxes.
The calculated proton budgets clearly show that it is the combination of changes in process rates and changes in buffering capacity that determines the net proton change of the system. Which of these two dominates depends on the season, depth and the process considered. However, it appears that variations in the process rates control the general pattern of proton cycling, while the buffering capacity dampens its signal with varying intensity. In 2012, this became especially apparent during the period of summer hypoxia, when the decrease in buffering capacity with depth led to a much shorter proton turnover time at depth compared with the surface. Of the process rates considered, the balance between primary production and respiration had the biggest impact on proton cycling. The influence of $\mathrm{CO}_{2}$ airsea exchange was most apparent during outgassing in autumn, while sedimentary TA and DIC fluxes impinged the proton balance in the deepest part of the basin. While the effect of vertical mixing on the proton balance was mostly negligible, horizontal exchange appeared to exert a major control on the proton budget of the basin.

This work highlights that process rates, buffering capacity and ambient $\mathrm{pH}$ are all essential compartments when determining the vulnerability of a system to changes in $\mathrm{pH}$. By constructing one of the first proton budgets originating from in situ measurements, this study shows the associated uncertainties and challenges for future studies. 


\section{Appendix A: Overdetermination of carbonate system}

\section{A1 A1 Contribution of particles and organic alkalinity to TA}

In oceanic research, samples for the determination of TA are typically not filtered before measurements (e.g. Dickson et al., 2007). In an open ocean setting, concentrations of suspended matter are usually low and its effect on TA may therefore be neglected. However, in highly productive regions, such as coastal regions, high concentrations of particulate organic matter and calcium carbonate $\left(\mathrm{CaCO}_{3}\right)$ particles are often found. In an incubation experiment, Kim et al. (2006) showed that the titration of surface sites on phytoplankton and bacterial cells can add significantly to the measured TA. By filtering seawater upon collection, particulates are removed and the contribution of particulate organic matter (POM) and $\mathrm{CaCO}_{3}$ particles to TA can be ignored.

We assessed the contribution of suspended particulate matter (SPM) to TA by calculating the difference between TA measured on unfiltered and filtered $(0.45 \mu \mathrm{m})$ seawater. This difference $\triangle \mathrm{TA}$, which could indicate the contribution of SPM to TA, is not significantly different from zero ( $t=0.1281, \mathrm{~d} f=190, P=0.898$; two-sided Student's $t$-test calculated using the package Stats in R), nor does it not show a clear pattern with TA (Fig. A1; blue triangles), $\mathrm{pH}_{\mathrm{T}}$ or SPM (results not shown). Additionally, the outliers in this data set could not unequivocally be correlated to events such as the phytoplankton bloom in July or high CR in May.

Additionally, dissolved organic matter (DOM) may contribute to TA, as DOM is composed of several compounds that have acid-base groups attached to them. The bulk of terrestrial-derived DOM consists of humic and fulvic acids and their contribution to estuarine TA and acid-base properties were described by Cai et al. (1998). In general, the contribution of DOM-associated acid-base groups to TA can be assessed using a chemical model set up by Oliver et al. (1983), which was calibrated for natural waters by Driscoll et al. (1989). However, the calibration performed by these authors was done on freshwater lakes with maximum $\mathrm{pH}<7.5$. Thus, their parameterisation might not be directly applicable to saline waters including Lake Grevelingen, where most DOM is derived from phytoplankton. Both in incubation experiments (Hernández-Ayon et al., 2007; Kim and Lee, 2009; Koeve and Oschlies, 2012) and in biologically active natural waters (Hernández-Ayon et al., 2007; Muller and Bleie, 2008) it has been shown that DOM resulting from phytoplankton may contribute significantly to seawater TA. The contribution of DOM to TA relies on two factors: the density of acid-base functional groups within the organic matter compounds and their associated $\mathrm{pK}_{a}$ values. Both of these factors depend on DOM quality and source material, and neither of them is well known for marine DOM. To highlight this complexity, the increase in TA per unit increase of DOM in phytoplankton culture experiments appears to be species-specific (Kim and Lee, 2009).

In theory, one would expect that TA calculated from DIC (and total concentrations of borate, ammonia, phosphate and other inorganic species contributing to TA) represents the inorganic, aqueous fraction of TA. When TA is measured directly using a filtered seawater sample, one implicitly includes TA derived from dissolved organic acids and bases. We evaluated the contribution of DOM to the total alkalinity by: (1) comparing TA calculated from $\mathrm{pH}$ and DIC with TA determined from filtered $(0.45 \mu \mathrm{m})$ seawater; and (2) applying the formulation of Driscoll et al. (1989) using concentrations of DOC.

A two-sided Student's $t$-test revealed that there was no significant difference between TA measured on filtered samples and TA calculated from DIC and $\mathrm{pH}_{\mathrm{T}}(t=-0.044$, $\mathrm{d} f=187, P=0.965)$. However, Fig. A1 shows that, in general, the difference between TA measured on filtered samples and TA calculated from DIC and $\mathrm{pH}$ (red squares) is positive in the lower range of TA values. A positive difference might indicate that DOM-associated acid-base groups increase TA. On the contrary, a negative difference was found in the higher range of TA values, indicating that DOM-associated groups decrease the acid neutralisation capacity of the water. When these data were plotted as a function of $\mathrm{pH}_{\mathrm{T}}$ or $\mathrm{DOC}$, no pattern was observed (results not shown). Similar to the difference between TA measured on unfiltered and filtered seawater, we found no correlation between the outliers in this data set and biogeochemical process rates.

The contribution of organic alkalinity to TA as calculated with the model calibrated by Driscoll et al. (1989) did not show any systematic variability and ranged between 16 and $32 \mu \mathrm{mol} \mathrm{kg}^{-1}$, with DOC ranging between 119 and $237 \mu \mathrm{mol} \mathrm{kg}^{-1}$ (see online supplementary information). Its pattern did not resemble the difference between TA measured from filtered samples and calculated TA, indicating that the model could not explain the current results. In the range of $\mathrm{pH}$ values observed at Den Osse, the operational $\mathrm{pK}$ value derived from the Driscoll et al. (1989) model, which is an average representative of various DOM-associated acid-base groups, ranged between 5.91 and 6.06, indicating that the majority of these groups were present in their basic form. However, this operational $\mathrm{pK}$ value is significantly lower than the $\mathrm{pK}_{\mathrm{a}}$ of organic acids associated with phytoplankton, which was found to be above 7 (Hernández-Ayon et al., 2007), indicating that the fraction of organic acid-base groups present in their basic form may be smaller. This would thus decrease the calculated contribution of DOC to TA. Additionally, the fraction of DOC that is releasing bases during phytoplankton blooms is unknown but may be higher than the $14 \%$ calibrated by Driscoll et al. (1989), which would mean that their model underestimates organic alkalinity in coastal systems. 


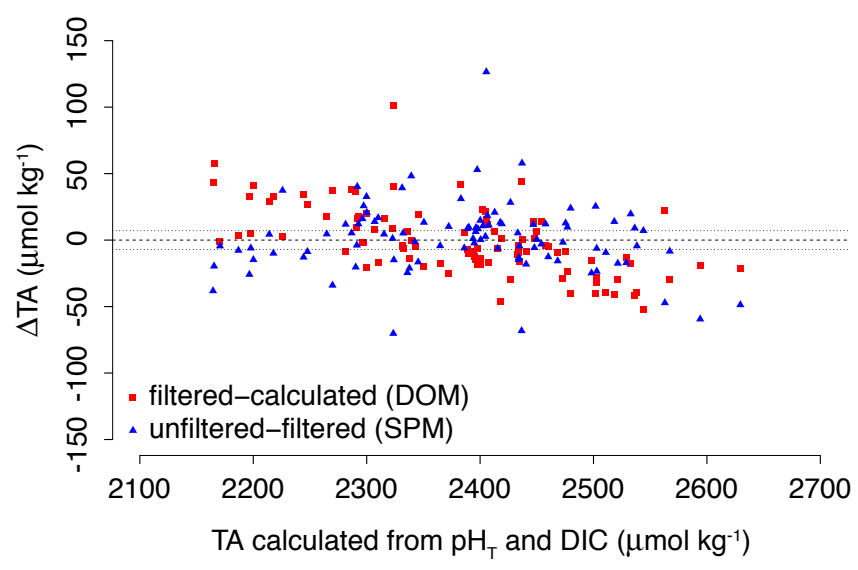

Figure A1. Differences in total alkalinity $\left(\Delta \mathrm{TA} ; \mu \mathrm{mol} \mathrm{kg}{ }^{-1}\right)$ measured on unfiltered and filtered $(0.45 \mu \mathrm{m})$ samples (blue triangles; representing the effect of particles) and between TA measured on filtered seawater and TA calculated from DIC and $\mathrm{pH}_{\mathrm{T}}$ (red squares; representing potential organic alkalinity), plotted as a function of TA calculated from DIC and $\mathrm{pH}_{\mathrm{T}}$. The dotted lines indicate the typical standard deviation of the difference between two measurements.

\section{A2 Comparison of measured and calculated $p \mathrm{CO}_{2}$ values}

During this study, we measured four parameters of the carbonate system (DIC, TA, $p \mathrm{CO}_{2}, \mathrm{pH}_{\mathrm{T}}$ ), while, theoretically, only two parameters are necessary for a full determination. Which two parameters can best be measured to describe the carbonate system is subject of an ongoing debate. Dickson et al. (2007) suggest that, if possible, it is always better to measure a parameter rather than calculate it from other parameters, since there are limitations to the accuracy of the carbonate system prediction when certain combinations of parameters are used. For instance, in a compilation of incubation studies it was found that calculating $p \mathrm{CO}_{2}$ from DIC and TA tends to underestimate $p \mathrm{CO}_{2}$ at high levels (i.e. $\sim 1000$ ppmv) by up to $30 \%$, for, as yet, unknown reasons (Hoppe et al., 2012).

In 2012, $p \mathrm{CO}_{2}$ calculated from DIC and $\mathrm{pH}_{\mathrm{T}}$ ranged between 189 and 1407 ppmv in the Den Osse basin. To check whether this natural system also showed internal inconsistencies, and to further highlight the complexity of an overdetermined system, we compared $p \mathrm{CO}_{2}$ values calculated with different combinations of TA, DIC and $\mathrm{pH}_{\mathrm{T}}$ with measured $p \mathrm{CO}_{2}$ values (Fig. A2). For each combination of parameters, we assessed their agreement with measured $p \mathrm{CO}_{2}$ by calculating the sum of squared differences. This calculation showed that using $\mathrm{pH}_{\mathrm{T}}$ and DIC provides the best agreement between measured and calculated $p \mathrm{CO}_{2}$. The highest sum of squares was found when using DIC with either filtered or unfiltered TA, which is another indication of the uncertainties introduced when using this combination of carbonate system parameters in non-open-ocean settings. Another

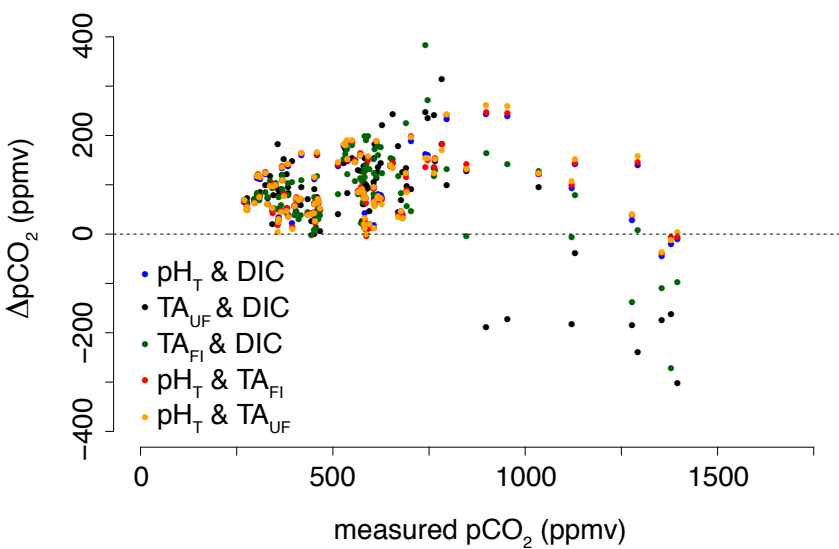

Figure A2. Differences in partial pressure of $\mathrm{CO}_{2}\left(\Delta p \mathrm{CO}_{2} ; \mathrm{ppmv}\right)$ measured by the headspace technique using gas chromatography and calculated using a suite of parameter combinations $\left(\mathrm{pH}_{\mathrm{T}}\right.$ and DIC, TA and DIC, $\mathrm{pH}_{\mathrm{T}}$ and TA). TAFI and TAUF indicate TA measured on filtered and unfiltered samples, respectively.

feature in Fig. A2 is that calculated $p \mathrm{CO}_{2}$ values are generally lower than measured values, as indicated by a positive $\Delta p \mathrm{CO}_{2}$. Only in the higher range of measured $p \mathrm{CO}_{2}$ ( $>$ ca. $1000 \mathrm{ppmv}$ ) and when TA is used as a starting parameter is the calculated $p \mathrm{CO}_{2}$ mostly higher than the measured $p \mathrm{CO}_{2}$. A closer look at these data reveals that all samples below the pycnocline in August show higher calculated than measured $p \mathrm{CO}_{2}$ when DIC and either of the TA measurements are used as the parameter combination. These differences range between 3 and 299 ppmv (0-21.4\%) and are generally higher when unfiltered TA samples are used. Furthermore, the two points where TA calculated from $\mathrm{pH}$ and DIC is highest (2593 and $2629 \mu \mathrm{mol} \mathrm{kg}{ }^{-1}$; Fig. A1), which are the samples taken at 25 and $32 \mathrm{~m}$ depth in July, also show a higher calculated than measured $p \mathrm{CO}_{2}$ when DIC and unfiltered TA are used as parameter combination (differences of 185 and 169 ppmv or 20.6 and $17.6 \%$, respectively).

\section{A3 Concluding remarks}

To summarise, these results suggest that, especially in hypoxic natural waters, TA cannot unequivocally be chosen as one of the two parameters necessary to quantify the carbonate system. Additionally, the Den Osse data set cannot be used to draw any clear conclusions on the effect of DOM and SPM on TA. This conclusion supports our choice of using $\mathrm{pH}_{\mathrm{T}}$ and $\mathrm{DIC}$ for the carbonate system calculations. 


\section{The Supplement related to this article is available online at doi:10.5194/bg-12-1561-2015-supplement.}

Acknowledgements. We thank Silvia Hidalgo Martinez, Pieter van Rijswijk, Alissa Zuijdgeest, Thomas Boerman and the crew of the R/V Luctor (Peter Coomans and Marcel Kristalijn) for their support during the sampling campaigns. The following people of the analytical lab of NIOZ-Yerseke and Utrecht University are thanked: Jan Sinke and Anton Tramper for the nutrient analyses; Jurian Brasser for the DIC and TA analyses; Yvonne van der Maas for the DOC analyses; Dineke van de Meent for the $\mathrm{H}_{2} \mathrm{~S}$ analyses. This research was financially supported by the Netherlands Organisation of Scientific Research (NWO; Sea and Coastal Research fund 83910502), the European Research Council under the European Community's Seventh Framework Program (ERC Starting Grants 278364 and 306933), the Fonds National de la Recherche Scientifique (FNRS Belgium), the Darwin Center for Biogeosciences, and the Netherlands Centre for Earth System Sciences. Finally, we thank Wei-Jun Cai, Helmuth Thomas and an anonymous reviewer for their constructive feedback that has greatly improved our manuscript.

Edited by: C. Rabouille

\section{References}

Bannink, B. A., Van der Meulen, J. H. M., and Nienhuis, P. H.: Lake Grevelingen: from an estuary to a saline lake. An introduction, Netherlands J. Sea Res., 18, 179-190, 1984.

Ben-Yaakov, S.: pH buffering of pore water of recent anoxic marine sediments, Limnol. Oceanogr., 18, 86-94, 1973.

Borges, A. V. and Gypens, N.: Carbonate chemistry in the coastal zone responds more strongly to eutrophication than ocean acidification, Limnol. Oceanogr., 55, 346-353, 2010.

Brewer, P. G. and Peltzer, E. T.: Limits to marine life, Science, 324, 347-348, 2009.

Burnett, L. E.: The challenges of living in hypoxic and hypercapnic aquatic environments, Integr. Comp. Biol., 37, 633-640, 1997.

Cadée, G. C. and Hegeman, J.: Historical phytoplankton data of the Marsdiep, Hydrobiol. Bull., 24, 111-118, 1991.

Cai, W.-J., Wang, Y., and Hodson, R. E.: Acid-base properties of dissolved organic matter in the estuarine waters of Georgia, USA, Geochim. Cosmochim. Acta, 62, 473-483, 1998.

Cai, W.-J., Hu, X., Huang, W.-J., Murrell, M. C., Lehrter, J. C., Lohrenz, S. E., Chou, W.-C., Zhai, W., Hollibaugh, J. T., Wang, Y., Zhao, P., Guo, X., Gundersen, K., Dai, M., and Gong, G.-C.: Acidification of subsurface coastal waters enhanced by eutrophication, Nat. Geosci., 4, 766-770, 2011.

Cantoni, C., Luchetta, A., Celio, M., Cozzi, S., Raicich, F., and Catalano, G.: Carbonate system variability in the Gulf of Trieste (North Adriatic Sea), Estuar. Coast. Shelf Sci., 115, 51-62, 2012.

Diaz, R. J. and Rosenberg, R.: Spreading dead zones and consequences for marine ecosystems, Science, 321, 926-929, 2008.

Dickson, A. G. and Millero, F. J.: A comparison of the equilibrium constants for the dissociation of carbonic acid in seawater media, Deep Sea Res. Pt. A, 34, 1733-1743, 1987.
Dickson, A. G., Sabine, C. L., and Christian, J. R. (Eds.): Guide to Best Practices for Ocean $\mathrm{CO}_{2}$ Measurements, PICES Special Publication 3, 2007.

Dickson, A. G.: The carbon dioxide system in seawater: equilibrium chemistry and measurements, in: Guide to Best Practices for Ocean Acidification Research and Data Reporting, edited by: Riebesell, U., Fabry, V. J., Hansson, L., and Gattuso, J.-P., Luxembourg, Publications Office of the European Union, 17-40, 2010.

Dortch, Q.: The interaction between ammonium and nitrate uptake in phytoplankton, Mar. Ecol. Prog. Ser., 61, 183-201, 1990.

Driscoll, C. T., Fuller, R. D., and Schecher, W. D.: The role of organic acids in the acidification of surface waters in the Eastern U.S, Water. Air. Soil Pollut., 43, 21-40, 1989.

Duarte, C. M., Hendriks, I. E., Moore, T. S., Olsen, Y. S., Steckbauer, A., Ramajo, L., Carstensen, J., Trotter, J. A., and McCulloch, M.: Is ocean acidification an open-ocean syndrome?, Understanding anthropogenic impacts on seawater $\mathrm{pH}$, Estuar. Coast., 36, 221-236, 2013.

Edman, M. and Omstedt, A.: Modeling the dissolved $\mathrm{CO}_{2}$ system in the redox environment of the Baltic Sea, Limnol. Oceanogr., 58, 74-92, 2013.

Egleston, E. S., Sabine, C. L., and Morel, F. M. M.: Revelle revisited: Buffer factors that quantify the response of ocean chemistry to changes in DIC and alkalinity, Global Biogeochem. Cy., 24, GB1002, doi:10.1029/2008GB003407, 2010.

Eilers, P. H. C. and Peeters, J. C. H.: A model for the relationship between light intensity and the rate of photosynthesis in phytoplankton, Ecol. Modell., 42, 199-215, 1988.

Feely, R. A., Alin, S. R., Newton, J., Sabine, C. L., Warner, M., Devol, A., Krembs, C., and Maloy, C.: The combined effects of ocean acidification, mixing, and respiration on $\mathrm{pH}$ and carbonate saturation in an urbanized estuary, Estuar. Coast. Shelf Sci., 88, 442-449, 2010.

Feistel, R.: A Gibbs function for seawater thermodynamics for -6 to $80^{\circ} \mathrm{C}$ and salinity up to $120 \mathrm{gkg}-1$, Deep Sea Res. Pt. I, 55, 1639-1671, 2008.

Frankignoulle, M.: A complete set of buffer factors for acid/base $\mathrm{CO}_{2}$ system in seawater, J. Mar. Syst., 5, 111-118, 1994.

Frankignoulle, M. and Distèche, A.: $\mathrm{CO}_{2}$ chemistry in the water column above a Posidonia seagrass bed and related air-sea exchanges, Oceanol. Acta, 7, 209-219, 1984.

Gazeau, F., Borges, A., Barrón, C., Duarte, C., Iversen, N., Middelburg, J., Delille, B., Pizay, M., Frankignoulle, M., and Gattuso, J.: Net ecosystem metabolism in a micro-tidal estuary (Randers Fjord, Denmark): evaluation of methods, Mar. Ecol. Prog. Ser., 301, 23-41, 2005a.

Gazeau, F., Gattuso, J.-P., Middelburg, J. J., Brion, N., Schiettecatte, L.-S., Frankignoulle, M., and Borges, A. V.: Planktonic and whole system metabolism in a nutrient-rich estuary (the Scheldt estuary), Estuaries, 28, 868-883, 2005b.

Hagens, M., Hunter, K. A., Liss, P. S., and Middelburg, J. J.: Biogeochemical context impacts seawater $\mathrm{pH}$ changes resulting from atmospheric sulfur and nitrogen deposition, Geophys. Res. Lett., 41, 935-941, 2014.

Hernández-Ayon, J. M., Zirino, A., Dickson, A. G., Camiro-Vargas, T., and Valenzuela, E.: Estimating the contribution of organic bases from microalgae to the titration alkalinity in coastal seawaters, Limnol. Oceanogr. Methods, 5, 225-232, 2007. 
Hofmann, A. F., Meysman, F. J. R., Soetaert, K., and Middelburg, J. J.: A step-by-step procedure for $\mathrm{pH}$ model construction in aquatic systems, Biogeosciences, 5, 227-251, doi:10.5194/bg-5227-2008, 2008.

Hofmann, A. F., Middelburg, J. J., Soetaert, K., and Meysman, F. J. R.: pH modelling in aquatic systems with time-variable acidbase dissociation constants applied to the turbid, tidal Scheldt estuary, Biogeosciences, 6, 1539-1561, doi:10.5194/bg-6-15392009, 2009.

Hofmann, A. F., Middelburg, J. J., Soetaert, K., Wolf-Gladrow, D. A., and Meysman, F. J. R.: Proton cycling, buffering, and reaction stoichiometry in natural waters, Mar. Chem., 121, 246-255, 2010a.

Hofmann, A. F., Soetaert, K., Middelburg, J. J., and Meysman, F. J. R.: AquaEnv?: An aquatic acid-base modelling environment in R, Aquat. Geochem., 16, 507-546, 2010 b.

Hofmann, G. E., Smith, J. E., Johnson, K. S., Send, U., Levin, L. A., Micheli, F., Paytan, A., Price, N. N., Peterson, B., Takeshita, Y., Matson, P. G., Crook, E. D., Kroeker, K. J., Gambi, M. C., Rivest, E. B., Frieder, C. A., Yu, P. C., and Martz, T. R.: Highfrequency dynamics of ocean $\mathrm{pH}$ : a multi-ecosystem comparison, PLoS One, 6, e28983, doi:10.1371/journal.pone.0028983, 2011.

Hoppe, C. J. M., Langer, G., Rokitta, S. D., Wolf-Gladrow, D. A., and Rost, B.: Implications of observed inconsistencies in carbonate chemistry measurements for ocean acidification studies, Biogeosciences, 9, 2401-2405, doi:10.5194/bg-9-2401-2012, 2012.

Howarth, R., Chan, F., Conley, D. J., Garnier, J., Doney, S. C., Marino, R., and Billen, G.: Coupled biogeochemical cycles: eutrophication and hypoxia in temperate estuaries and coastal marine ecosystems, Front. Ecol. Environ., 9, 18-26, 2011.

Jury, C. P., Thomas, F. I. M., Atkinson, M. J., and Toonen, R. J.: Buffer capacity, ecosystem feedbacks, and seawater chemistry under global change, Water, 5, 1303-1325, 2013.

Kim, H.-C. and Lee, K.: Significant contribution of dissolved organic matter to seawater alkalinity, Geophys. Res. Lett., 36, L20603, doi:10.1029/2009GL040271, 2009.

Kim, H.-C., Lee, K., and Choi, W.: Contribution of phytoplankton and bacterial cells to the measured alkalinity of seawater, Limnol. Oceanogr., 51, 331-338, 2006.

Knap, A. H., Michaels, A. F., and Close, A.: The JGOFS Protocols, Intergovernmental Oceanographic Commission, 1994.

Koeve, W. and Oschlies, A.: Potential impact of DOM accumulation on $\mathrm{fCO}_{2}$ and carbonate ion computations in ocean acidification experiments, Biogeosciences, 9, 3787-3798, doi:10.5194/bg-93787-2012, 2012.

Lancelot, C., Gypens, N., Billen, G., Garnier, J., and Roubeix, V.: Testing an integrated river-ocean mathematical tool for linking marine eutrophication to land use: The Phaeocystis-dominated Belgian coastal zone (Southern North Sea) over the past 50 years, J. Mar. Syst., 64, 216-228, 2007.

Lee, D. Y., Owens, M. S., Doherty, M., Eggleston, E. M., Hewson, I., Crump, B. C., and Cornwell, J. C.: The effects of oxygen transition on community respiration and potential chemoautotrophic production in a seasonally stratified anoxic estuary, Estuar. Coast., 38, 104-117, 2015.

MacIsaac, J. J. and Dugdale, R. C.: Interactions of light and inorganic nitrogen in controlling nitrogen uptake in the sea, Deep Sea Res. Oceanogr. Abstr., 19, 209-232, 1972.
Malkin, S. Y., Rao, A. M., Seitaj, D., Vasquez-Cardenas, D., Zetsche, E.-M., Hidalgo-Martinez, S., Boschker, H. T., and Meysman, F. J.: Natural occurrence of microbial sulphur oxidation by long-range electron transport in the seafloor., ISME J., 8, 1843-1854, 2014.

Mehrbach, C., Culberson, C. H., Hawley, J. E., and Pytkowicz, R. M.: Measurement of the apparent dissociation constants of carbonic acid in seawater at atmospheric pressure, Limnol. Oceanogr., 18, 897-907, 1973.

Meijers, E. and Groot, S.: Deltamodel - hulpmiddel ter ondersteuning van het beheer en beleid van de zuidwestelijke Delta, Delft, Netherlands., 2007.

Melzner, F., Thomsen, J., Koeve, W., Oschlies, A., Gutowska, M. A., Bange, H. W., Hansen, H. P., and Körtzinger, A.: Future ocean acidification will be amplified by hypoxia in coastal habitats, Mar. Biol., 160, 1875-1888, 2013.

Middelburg, J. J. and Nieuwenhuize, J.: Nitrogen uptake by heterotrophic bacteria and phytoplankton in the nitrate-rich Thames estuary, Mar. Ecol. Prog. Ser., 203, 13-21, 2000.

Middelburg, J. J. and Herman, P. M. J.: Organic matter processing in tidal estuaries, Mar. Chem., 106, 127-147, 2007.

Morel, F. M. M. and Hering, J. G.: Principles and Applications of Aquatic Chemistry, First Edit., Wiley-Interscience, 1993.

Mucci, A., Starr, M., Gilbert, D., and Sundby, B.: Acidification of Lower St. Lawrence Estuary bottom waters, Atmos.-Oc., 49, 206-218, 2011.

Muller, F. L. L. and Bleie, B.: Estimating the organic acid contribution to coastal seawater alkalinity by potentiometric titrations in a closed cell, Anal. Chim. Acta, 619, 183-91, 2008.

Nienhuis, P. H.: An ecosystem study in Lake Grevelingen, a former estuary in the SW Netherlands, Kieler Meeresforschungen. Sonderh., 4, 247-255, 1978.

Nienhuis, P. H. and Huis in 't Veld, J. C.: Grevelingen: from an estuary to a saline lake, Water Sci. Technol., 16, 27-50, 1984.

Nixon, S. W.: Coastal marine eutrophication: a definition, social causes, and future concerns, Ophelia, 41, 199-219, 1995.

Nolte, A., Troost, T., de Boer, G., Spiteri, C., and van Wesenbeeck, B.: Verkenning oplossingsrichtingen voor een betere waterkwaliteit en ecologische toestand van het Grevelingenmeer, Delft, Netherlands, 2008.

Oliver, B. G., Thurman, E. M., and Malcolm, R. L.: The contribution of humic substances to the acidity of colored natural waters, Geochim. Cosmochim. Acta, 47, 2031-2035, 1983.

Omstedt, A., Gustafsson, E., and Wesslander, K.: Modelling the uptake and release of carbon dioxide in the Baltic Sea surface water, Cont. Shelf Res., 29, 870-885, 2009.

Orr, J. C., Fabry, V. J., Aumont, O., Bopp, L., Doney, S. C., Feely, R. A., Gnanadesikan, A., Gruber, N., Ishida, A., Joos, F., Key, R. M., Lindsay, K., Maier-Reimer, E., Matear, R., Monfray, P., Mouchet, A., Najjar, R. G., Plattner, G.-K., Rodgers, K. B., Sabine, C. L., Sarmiento, J. L., Schlitzer, R., Slater, R. D., Totterdell, I. J., Weirig, M.-F., Yamanaka, Y., and Yool, A.: Anthropogenic ocean acidification over the twenty-first century and its impact on calcifying organisms, Nature, 437, 681-686, 2005.

Peperzak, L. and Poelman, M.: Mass mussel mortality in The Netherlands after a bloom of Phaeocystis globosa (prymnesiophyceae), J. Sea Res., 60, 220-222, 2008.

Philippart, C. J. M., Beukema, J. J., Cadée, G. C., Dekker, R., Goedhart, P. W., van Iperen, J. M., Leopold, M. F., and Herman, P. M. 
J.: Impacts of nutrient reduction on coastal communities, Ecosystems, 10, 96-119, 2007.

Pierrot, D., Lewis, E., and Wallace, D. W. R.: MS Excel program developed for $\mathrm{CO}_{2}$ system calculations, Oak Ridge, Tennessee, USA, 2006.

Pieters, J. P. F., Bannink, B. A., and van de Kamer, J. P. G.: Een mathematisch model van de chlorideen zuurstofhuishouding van het Grevelingenmeer tijdens de uitwisseling met zeewater, Middelburg, Netherland, 1985.

Provoost, P., van Heuven, S., Soetaert, K., Laane, R. W. P. M., and Middelburg, J. J.: Seasonal and long-term changes in $\mathrm{pH}$ in the Dutch coastal zone, Biogeosciences, 7, 3869-3878, doi:10.5194/bg-7-3869-2010, 2010.

Redfield, A. C., Ketchum, B. H., and Richards, F. A.: The influence of organisms on the composition of sea-water, in: The Composition of Seawater. Comparative and Descriptive Oceanography, edited by: Hill, M. N., Interscience Publishers, New York, 26-77, 1963.

Regnier, P., Wollast, R., and Steefel, C. I.: Long-term fluxes of reactive species in macrotidal estuaries: Estimates from a fully transient, multicomponent reaction-transport model, Mar. Chem., 58, 127-145, 1997.

Revelle, R. and Suess, H. E.: Carbon dioxide exchange between atmosphere and ocean and the question of an increase of atmospheric $\mathrm{CO}_{2}$ during the past decades, Tellus, 9, 18-27, 1957.

Riley, G. A.: Plankton studies. II. The western north Atlantic, MayJune 1939, J. Mar. Res., 2, 145-162, 1939.

Sayama, M., Risgaard-Petersen, N., Nielsen, L. P., Fossing, H., and Christensen, P. B.: Impact of bacterial $\mathrm{NO}_{3}^{-}$transport on sediment biogeochemistry, Appl. Environ. Microbiol., 71, 75757577, 2005.

Schulz, K. G. and Riebesell, U.: Diurnal changes in seawater carbonate chemistry speciation at increasing atmospheric carbon dioxide, Mar. Biol., 160, 1889-1899, 2013.

Seitaj, D., Schauer, R., Sulu-Gambari, F., Malkin, S. Y., Hidalgo Martinez, S., Slomp, C. P., and Meysman, F. J. R.: Temporal succession of cryptic sulphur cycling in a seasonally hypoxic basin, in preparation, 2015a.

Seitaj, D., Sulu-Gambari, F., Malkin, S. Y., Burdorf, L., Slomp, C. P., and Meysman, F. J. R.: Sediment mineralization and benthic oxygen dynamics in a seasonally hypoxic basin, in preparation, 2015b.

Shadwick, E. H., Trull, T. W., Thomas, H., and Gibson, J. A. E.: Vulnerability of polar oceans to anthropogenic acidification: comparison of Arctic and Antarctic seasonal cycles., Sci. Rep., 3, 2339, doi:10.1038/srep02339, 2013.

Shaw, E. C., McNeil, B. I., Tilbrook, B., Matear, R., and Bates, M. L.: Anthropogenic changes to seawater buffer capacity combined with natural reef metabolism induce extreme future coral reef $\mathrm{CO}_{2}$ conditions, Glob. Chang. Biol., 19, 1632-1641, 2013.

Simpson, J. H.: The shelf-sea fronts: implications of their existence and behaviour, Philos. Trans. R. Soc. A Math. Phys. Eng. Sci., 302, 531-543, 1981.

Soetaert, K., Hofmann, A. F., Middelburg, J. J., Meysman, F. J. R., and Greenwood, J.: The effect of biogeochemical processes on pH, Mar. Chem., 105, 30-51, 2007.

Strickland, J. D. and Parsons, T. R.: A Practical Handbook of Seawater Analysis, $2^{\text {nd }}$ Edition, Bulletin 167, Fisheries Research Board of Canada, Ottawa, Canada, 1972.
Stumm, W. and Morgan, J. J.: Aquatic Chemistry: Chemical Equilibria and Rates in Natural Waters, 3rd edition, John Wiley \& Sons, Inc., 1996.

Sullivan, T., Byrne, C., Harman, L., Davenport, J., McAllen, R., and Regan, F.: Determination of spatial and temporal variability of $\mathrm{pH}$ and dissolved oxygen concentrations in a seasonally hypoxic semi-enclosed marine basin using continuous monitoring, Anal. Methods, 6, 5489-5497, 2014.

Sunda, W. G. and Cai, W.-J.: Eutrophication induced $\mathrm{CO}_{2-}$ acidification of subsurface coastal waters: interactive effects of temperature, salinity, and atmospheric $p \mathrm{CO}_{2}$, Environ. Sci Technol., 46, 10651-10659, 2012.

Sundquist, E. T., Plummer, L. N., and Wigley, T. M.: Carbon dioxide in the ocean surface: the homogeneous buffer factor, Science, 204, 1203-1205, 1979.

Taguchi, F. and Fujiwara, T.: Carbon dioxide stored and acidified low oxygen bottom waters in coastal seas, Japan, Estuar. Coast. Shelf Sci., 86, 429-433, 2010.

Thomas, H., Prowe, A. E. F., van Heuven, S., Bozec, Y., de Baar, H. J. W., Schiettecatte, L.-S., Suykens, K., Koné, M., Borges, A. V., Lima, I. D., and Doney, S. C.: Rapid decline of the $\mathrm{CO}_{2}$ buffering capacity in the North Sea and implications for the North Atlantic Ocean, Global Biogeochem. Cycles, 21, GB4001, doi:10.1029/2006GB002825, 2007.

Verschuur, G. L.: Transparency measurements in Garner Lake, Tennessee: the relationship between Secchi depth and solar altitude and a suggestion for normalization of Secchi depth data, Lake Reserv. Manag., 13, 142-153, 1997.

Wallace, R. B., Baumann, H., Grear, J. S., Aller, R. C., and Gobler, C. J.: Coastal ocean acidification: The other eutrophication problem, Estuar. Coast. Shelf Sci., 148, 1-13, 2014.

Wang, B., Chen, J., Jin, H., Li, H., and Xu, J.: Inorganic carbon parameters responding to summer hypoxia outside the Changjiang Estuary and the related implications, J. Ocean Univ. China, 12, 568-576, 2013.

Wanninkhof, R.: Relationship between wind speed and gas exchange over the ocean, J. Geophys. Res., 97, 7373-7382, doi:10.1029/92JC00188, 1992.

Weiss, R. F.: Carbon dioxide in water and seawater: the solubility of a non-ideal gas, Mar. Chem., 2, 203-215, 1974.

Weiss, R. F.: Determinations of carbon dioxide and methane by dual catalyst flame ionization chromatography and nitrous oxide by electron capture chromatography, J. Chromatogr. Sci., 19, 611616, 1981.

Wetsteyn, L. P. M. J.: Grevelingenmeer: meer kwetsbaar?, Lelystad, Netherlands, 2011.

Wetsteyn, L. P. M. J. and Kromkamp, J. C.: Turbidity, nutrients and phytoplankton primary production in the Oosterschelde (The Netherlands) before, during and after a large-scale coastal engineering project (1980-1990), Hydrobiologia, 282/283, 61-78, 1994.

Wootton, J. T. and Pfister, C. A.: Carbon system measurements and potential climatic drivers at a site of rapidly declining ocean $\mathrm{pH}$ PLoS One, 7, e53396, doi:10.1371/journal.pone.0053396, 2012.

Yates, K. K., Dufore, C., Smiley, N., Jackson, C., and Halley, R. B.: Diurnal variation of oxygen and carbonate system parameters in Tampa Bay and Florida Bay, Mar. Chem., 104, 110-124, 2007.

Zhai, W., Zhao, H., Zheng, N., and Xu, Y.: Coastal acidification in summer bottom oxygen-depleted waters in northwestern- 
northern Bohai Sea from June to August in 2011, Chinese Sci. Bull., 57, 1062-1068, 2012.
Zhang, J.-Z.: The use of $\mathrm{pH}$ and buffer intensity to quantify the carbon cycle in the ocean, Mar. Chem., 70, 121-131, 2000. 